BANCA D'ITALIA

E U ROS I S T E M A

Temi di discussione

(Working Papers)

Dating the euro area business cycle: an evaluation

by Claudia Pacella 



\section{BANCA D'ITALIA}

E U ROS I S T E M A

\section{Temi di discussione}

(Working Papers)

Dating the euro area business cycle: an evaluation

by Claudia Pacella

Number 1332 - April 2021 
The papers published in the Temi di discussione series describe preliminary results and are made available to the public to encourage discussion and elicit comments.

The views expressed in the articles are those of the authors and do not involve the responsibility of the Bank.

Editorial Board: Federico Cingano, Marianna Riggi, Monica Andini, Audinga Baltrunaite, Marco Bottone, Davide Delle Monache, Sara Formai, Francesco Franceschi, Adriana Grasso, Salvatore lo Bello, Juho Taneli Makinen, Luca Metelli, Marco Savegnago.

Editorial Assistants: Alessandra Giammarco, Roberto Marano.

ISSN 1594-7939 (print)

ISSN 2281-3950 (online)

Printed by the Printing and Publishing Division of the Bank of Italy 


\title{
DATING THE EURO AREA BUSINESS CYCLE: AN EVALUATION
}

\author{
by Claudia Pacella*
}

\begin{abstract}
In this paper we study the business cycle dating formulated by the CEPR committee for the euro area. We first compare recessions as defined by the CEPR to those obtained using alternative methodologies (e.g. Bry-Boschan algorithm) and we find that the CEPR dating is not fully in line with other dating rules that are based only on GDP dynamics, thus confirming that the committee considers a broader set of variables. We then evaluate the classification of economic activity in recessions and expansions; the underlying business cycle is either based on a single variable or estimated as a latent factor that captures the comovements of several macroeconomic series. We find that the CEPR chronology is more consistent with the estimated common factor than with what is implied by methods solely based on GDP. Finally, we analyze which real variables drive the classification of economic activity by the CEPR and we find that the properties of the CEPR chronology are mainly related to the dynamics of demand components, especially final consumption, and employment.
\end{abstract}

JEL Classification: E32, C38.

Keywords: business fluctuations, cycle, factor models.

DOI: $10.32057 / 0$. TD.2021.1332

\section{Contents}

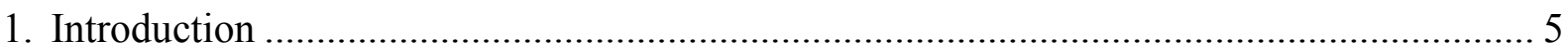

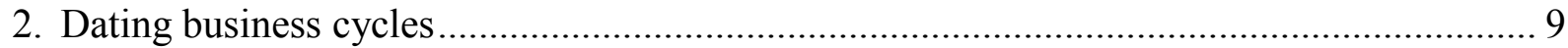

2.1 CEPR Dating Committee for the euro area .......................................................... 9

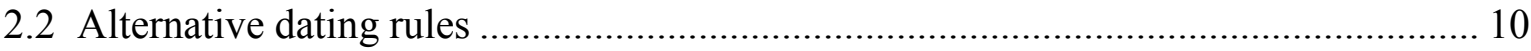

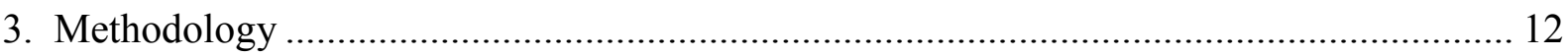

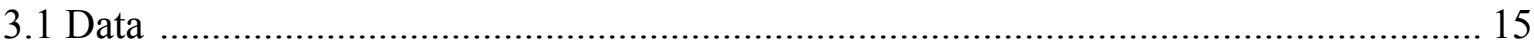

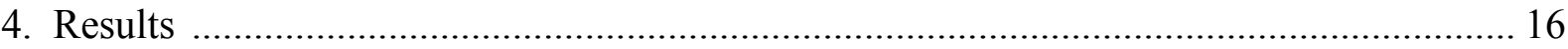

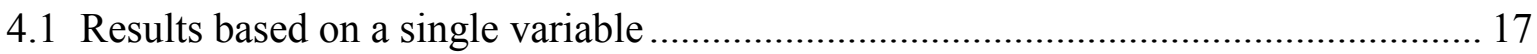

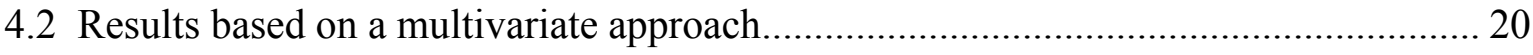

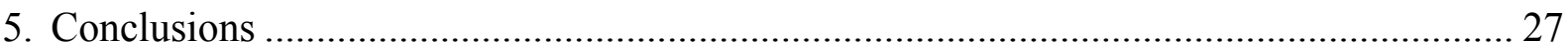

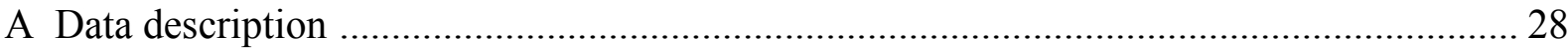

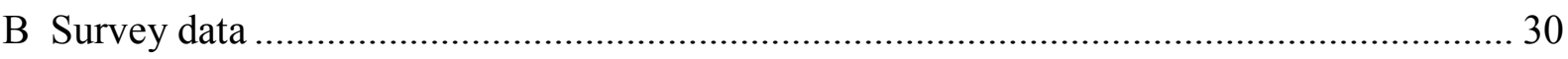

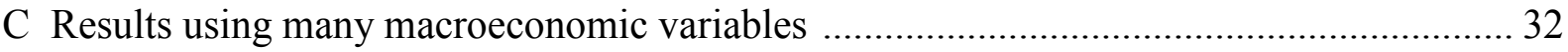

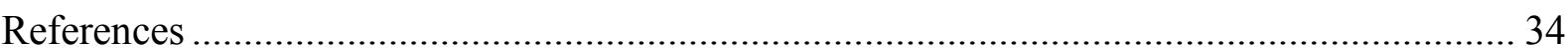

\footnotetext{
* Bank of Italy, Directorate General for Economics, Statistics and Research, Monetary Policy and Economic Outlook Directorate.
} 



\section{$1 \quad$ Introduction $^{1}$}

Since the Great financial crisis, the attention on business cycle analysis has strongly increased. Non-linear models such as regime-switching models have become popular tools to estimate the probability a variable to be in one of its possible states (Hamilton, 1989). The underlying idea is that macroeconomic variables behave according to different dynamics during expansionary and contractionary periods. In the last decade the literature on recession probabilities has further developed. The performance of non-linear models is usually tested vis-à-vis the recession periods. This exercise implicitly assumes that the target variable, which consists of a specific classification into recessions and expansions, is correctly identified.

In the euro area the chronology formulated by the CEPR is well-established, likewise the one for the US by the NBER. In this paper we evaluate the business cycle chronology of the euro area as identified by the CEPR. This analysis is relevant for both policymakers and academics interested in using the CEPR dating.

The aim of the paper is twofold. Firstly, we compare the turning points underlying the CEPR dating with those obtained using other possible alternatives, such as mechanical rules on one single variable or more sophisticated multivariate models. Secondly, we analyze which real variables drive the classification of economic activity by the CEPR.

We relate to the stream of literature studying the accuracy of business cycle chronologies. However, as not many official chronologies are available, to our knowledge the only paper evaluating a comparable consolidated dating is Berge and Jordà (2011) on the NBER dating for the US. They find that the NBER chronology is consistent with the dynamics of US business cycle. On the other hand, many methodologies to estimate turning points have been proposed and we compare those to the CEPR classification. Most methods rely on only one time series and they consist of nonparametric rules: the most popular are the Bry and Boschan (1971) algorithm and the 'rule of thumb' on GDP (Shiskin, 1974). A statistical model which was introduced to estimate the probability of transition between the two states of the business cycle is the regime-switching model (Goldfeld and Quandt, 1973; Hamilton, 1989; 1994). Chauvet and Piger (2008) and Hamilton (2011) find that both the Markov-switching model and the Bry-Boschan algorithm are very accurate in matching NBER dates. Other methodologies employed for turning points detection include factor models, which exploit the information common to many macroeconomic variables without

\footnotetext{
${ }^{1}$ I wish to thank Travis Berge, Fabio Busetti, Michele Caivano, Domenico Giannone, Adrian Pagan, Oscar Jorda, Stefano Neri, and Philippe Weil for their helpful comments and suggestions. I acknowledge the editor and two anonymous referees for their useful remarks.
} 
just choosing one (Stock and Watson, 2002; 2014). Our paper complements the existing literature with evidence on the euro area business cycle, with a specific focus on the CEPR chronology.

With respect to the US, for the euro area the exercise is further challenging, because time series are relatively short and business cycles of different countries have not completely converged towards a common business cycle, especially after the Sovereign Debt Crisis. The CEPR euro area business cycle dating Committee defines the chronology of recessions and expansions of the euro area by identifying turning points since 2003. The committee considers the euro area as including the original eleven member countries for the period ranging from 1970 to 1999 and in its changing composition after 1999. The committee detects turning points looking at the dynamics of several macroeconomic aggregates. The issue arises because the classification of business cycle does not only depend mechanically on the quarterly growth of GDP or on a fixed threshold of a selected indicator. The classification of economic activity is very difficult, because it is even ex-post unobservable, and it does not rely on one single variable.

As in Burns and Mitchell (1946) the business cycle is defined as "a type of fluctuation found in the aggregate economic activity of nations that organize their work mainly in business enterprises: a cycle consists of expansions occurring at about the same time in many economic activities, followed by similarly general recessions, contractions, and revivals which merge into the expansion phase of the next cycle; this sequence of changes is recurrent but not periodic; in duration business cycles vary from more than one year to ten or twelve years; they are not divisible into shorter cycles of similar character with amplitudes approximating their own."

In principle two approaches on business cycle exist. The growth or deviation cycle approach distinguishes four phases of the business cycle depending on the deviations from the long-term trend using the GDP as reference series. The phases of the deviation cycle are therefore defined according to the output gap and the actualversus-trend growth as expansion, downturn, recession and recovery. An expansion or boom occurs when the output gap is positive and GDP growth is above potential growth. After that, economy faces downturn when activity is still above the trend, but deteriorating. A recession or slow-down happens when the output gap becomes negative and the real growth is below potential growth. Finally, when at last activity is below the trend but improving the economy is in recovery or upturn. The problem of this approach is that it requires the estimation of the unobservable long-term trend. The classical approach (Burns and Mitchell, 1946; Mintz, 1969) distinguishes two phases depending on the general economic situation. This is the approach followed by the NBER and CEPR for dating peaks and troughs in the US 
and the euro area respectively. The advantage of this approach is that it relies on observable hard data, entailing less uncertainty than in the growth cycle approach. Under this approach, the phases are recession and expansion. A recession or contraction is characterized by a sustained decline in economic activity (e.g. real GDP), while the rest of the time economy is in expansion.

Following Burns and Mitchell (1946), the so-called 'reference cycle' is described either by one single variable capturing the general state of the economy or by a latent factor obtained from a big dataset including many 'specific cycles'. Among the several approaches in the literature, the most predominant way to estimate the reference cycle using many variables are factor models (Forni et al., 2000; Stock and Watson, 2002). In the last two decades a lot of indicators have been constructed in order to track the business cycle of many countries, some of which are published by private institutions, such as the Conference Board ${ }^{2}$ and ECRI. ${ }^{3}$

For the euro area the business cycle is well described by Eurocoin ${ }^{4}$ (Altissimo et al., 2001; 2010). The OECD also publishes Composite Leading Indicators $\left(\mathrm{CLIs}^{5}\right.$ ) for many countries.

From a statistical point of view, the issue the committee faces consists in a classification problem of the business cycle, which is itself represented as a mixture of two distributions, one for recessions and the other for expansions. Figure 1 shows the density distribution of the quarter-on-quarter growth rate of GDP in the two states of the economy obtained with gaussian kernel. The mode of the distribution of downturns is $-1.1 \%$ with values ranging from $-15.2 \%$ to $4.8 \%$ and a standard deviation of 3.1 ; the distribution of upturns is centered around $2.4 \%$ going from $-3.8 \%$ to $9.5 \%$ and a standard deviation of 1.9. The figure illustrates that high magnitude of growth rates of GDP are categorized as expansion or recession if positive or negative respectively, while the classification of growth rates close to zero is not straightforward. As Berge and Jordà (2011) highlight, the issue graphically consists in the overlapping region.

\footnotetext{
${ }^{2}$ See https://www.conference-board.org/data/bci.cfm.

${ }^{3}$ See https://www.businesscycle.com/ecri-reports-indexes/all-indexes.

${ }^{4}$ See https://eurocoin.cepr.org.

${ }^{5}$ See https://data.oecd.org/leadind/composite-leading-indicator-cli.htm.
} 


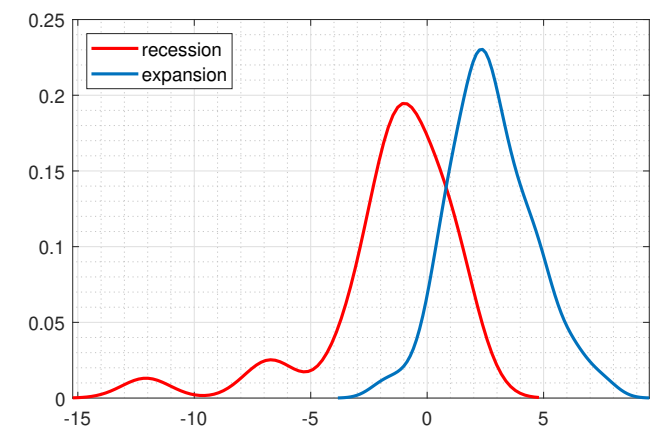

Figure 1: Density distribution of the growth rates of GDP in the two states of the economy (CEPR def.) obtained as gaussian kernel

Our analysis shows that the CEPR dating is not fully in line with other dating rules based only on GDP dynamics. One of the alternatives (the Markov-switching model) individuates only the sharpest recessionary episodes; the other mechanical rules (the Bry-Boschan algorithm and the rule of thumb), while reliable in replicating the CEPR turning points, detect shorter recessions with respect to the CEPR ones. These findings confirm that the committee considers more indicators. We then move to a multivariate framework and we find that the classification of economic activity appears to be mainly related to the dynamics of demand components, especially final consumption, and employment. Moreover, using the entire dataset we set up a model to compare with the CEPR dating and we find that the dating proposed by the CEPR committee consistently reflects the business cycle features common to most real macroeconomic time series.

The paper is structured as follows. Section 2 describes the different approaches to the business cycle with a focus on the business cycle dating committee. Section 3 illustrates the methodology and the evaluation criterion. Section 4 shows the main results. ${ }^{6}$ Section 5 concludes.

\footnotetext{
${ }^{6}$ Unfortunately out-of-sample analyses cannot be conducted because of the very short sample size. Most time series are indeed available or recoverable from 1995Q1 or even 1999Q1, thus capturing only the two recent recession episodes. Moreover, we should have been able to split the sample in a training sample, on which estimating the parameters, and an evaluation sample, where comparing forecasts and actual endogenous variable. This would result in an even shorter sample.
} 


\section{Dating business cycles}

\subsection{CEPR Dating Committee for the euro area}

The CEPR euro area business cycle dating Committee defines the chronology of recessions and expansions of the euro area by identifying turning points since 2003. The committee considers the euro area as including the original eleven member countries for the period ranging from 1970 to 1999 and in its changing composition after 1999.

The committee defines a recession as follows: ${ }^{7}$

"a significant decline in the level of economic activity, spread across the economy of the euro area, usually visible in two or more consecutive quarters of negative growth in GDP, employment and other measures of aggregate economic activity for the euro area as a whole".

The recession begins after a peak (excluded) and ends with a trough (included); the remaining time the economy experiences an expansion. According to the statement there are no constraints on magnitude and sign of the growth rate of the reference variables, which can be very low in both phases. The members of the committee do not disclose the methodology they employ and it is fair to suppose that a certain degree of subjective judgement could play a role in the final decision.

Regarding the cross-country heterogeneity, until 2011 the committee required turning points to appear in the same periods for most countries of the euro area. Since 2012 the committee's sole objective is to characterize euro area economic business cycle by adopting a dating criterion that only refers to aggregate euro area economic activity. Balkan (2012) studies whether this 'new' definition would require a change of the turning points set until then: the analysis confirms that no revisions on the dating were needed. However, analysis of main euro area countries' key economic indicators keep on being released in the key finding meaning they are helpful for a deeper understanding.

In general, the issue of understanding how reliable the chronology established by the CEPR arises because the features of the recessions and the cycles are not stable over time (Table 1).

\footnotetext{
${ }^{7}$ See https://cepr.org/content/business-cycle-dating-committee-methodology
} 
Table 1: Duration and amplitude of the cycles

\begin{tabular}{ccccccc}
\hline \multirow{2}{*}{ Turning point } & \multicolumn{5}{c}{ Duration in quarters } & \multirow{2}{*}{ Recession } \\
& & Expansion & \multicolumn{2}{c}{ Cycle } & Amplitude \\
\hline Peak $(\mathrm{P})$ & Trough $(\mathrm{T})$ & $\mathrm{P}$ to T & T to P & T to T & P to P & P to T \\
\hline 1974Q3 & 1975Q1 & 2 & 19 & 30 & 22 & -2.5 \\
1980Q1 & 1982Q3 & 10 & 20 & 44 & 48 & 0.4 \\
1992Q1 & 1993Q3 & 6 & 38 & 63 & 64 & -1.4 \\
2008Q1 & 2009Q2 & 5 & 58 & 15 & 14 & -5.7 \\
2011Q3 & 2013Q1 & 6 & 9 & & & -1.8 \\
\hline \multicolumn{2}{c}{ Average } & 5.8 & 28.8 & 38.0 & 37.0 & -2.3 \\
\hline
\end{tabular}

Note: Amplitude is computed as the loss in terms of real GDP between a peak and the following trough.

From 1970 to 2018 five recessions are identified lasting from 2 to 10 quarters, with an average duration of around 6 quarters; expansions last 7 years on average, varying from 9 to 58 quarters. The resulting cycles last almost 10 years, both when measured from peak to peak and from trough to trough. There is heterogeneity also in the amplitude of cycles, as measured by the loss in terms of real GDP during contractions: in the 1980Q2-1982Q3 recession GDP remained almost stable, while during the 2008Q2-2009Q2 one GDP fell of almost 6p.p.. On average in a recession GDP contracts for more than 2p.p..

\subsection{Alternative dating rules}

There are alternative methods to detect turning points.

The first method is a very popular rule of thumb often used by the media introduced by US Commissioner of Labor Statistics Shiskin (1974) in a New York Times article. The rule defines a recession when the economy experiences at least two consecutive negative quarters GDP growth or similarly six months for employment or industrial production. In the same article Shiskin actually describes other ways to detect a recession, not only depending on the duration: in terms of depth a recession occurs when real GDP declines by more than $1.5 \%$ or unemployment reaches $6 \%$, while in terms of diffusion the contraction of economic activity should be widespread, namely a decline in employment in more than $75 \%$ of industries.

The second method was introduced by Bry and Boschan (1971) to identify the turning points of a monthly time series. Harding and Pagan (2002) adapted the algorithm for quarterly time series, that is the typical case for macroeconomic data. It works 
as follows. Given a quarterly time series $X_{t}$ (e.g. GDP) in levels we define $x_{t}$ as a potential peak if $x_{t}$ is a local maximum, that is:

$$
x_{t}>x_{t-1}, \ldots, x_{t-w} \text { and } x_{t}>x_{t+1}, \ldots, x_{t+w}
$$

where $w$ is the window size, usually set to $w=2$ for quarterly data, $w=5$ for monthly data and $w=1$ for yearly data.

Prior to this a correction for outliers is applied. The optimization is subject to some constraints or censor rules:

- the distance between two consecutive peaks has to be at least $w$ periods

- the distance between the peak and the next trough has to be at least $w$ periods

- peaks and trough have to alternate

Correspondingly, the vice versa holds when it comes to troughs.

Once the turning points are found the sample period can be partitioned into periods (phases) of expansions (between troughs and peaks) and contractions (between peaks and troughs). The business cycle can therefore be represented as a state variable $S_{t}$, which takes value 0 in expansions and 1 in recessions, where a recession is defined as the time interval between a peak (excluded) and the trough (included).

The algorithm has advantages and disadvantages. On the one side, variables enter in levels without the need for any treatments to achieve stationarity. Canova (1998) studied how filters may alterate the properties of time series. On the other side, the choice of the parameter of the window size $w$ can draw a slightly different picture of the state of the economy.

The third method to classify economic activity is the regime-switching (hidden Markov mixture) model (Goldfeld and Quandt, 1973; Hamilton, 1989; 1994). According to Pagan (2019) this should be considered an indirect dating rule, since it involves using a parametric model to produce a dating rule. A variable can assume two states which change according to a Markov chain, whose underlying probabilities are estimated with a iterative Kalman filter algorithm with starting values set to the unconditional probabilities. The model is estimated on annualized quarteron-quarter GDP growth rates and it is defined as:

$$
y_{t}=\phi_{0, S_{t}}+\phi_{1} y_{t-1}+\epsilon_{t}, \epsilon_{t} \sim N(0, \sigma)
$$

The estimated transition probabilities are equal to $\operatorname{Prob}\left(S_{t}=0 \mid S_{t-1}=0\right)=0.98$ and $\operatorname{Prob}\left(S_{t}=1 \mid S_{t-1}=1\right)=0.25$, where the two states can easily be interpreted as expansion $\left(S_{t}=0\right)$ and recession $\left(S_{t}=1\right)$ given the corresponding intercepts $\left(\phi_{0,0}=-7.1, \phi_{0,1}=1.4\right)$. States are therefore estimated as periods when $\hat{y}_{t}>0.5$. 
Figure 2 reports the turning points as detected according to each of the criteria: the CEPR dating, the Bry-Boschan (BB) algorithm on GDP, the rule of thumb on GDP, and the Markov-switching model (MS) on GDP. Some considerations follow. First, the $\mathrm{BB}$ algorithm and the rule of thumb individuate five recessions each like the CEPR, while the MS model identifies only the three sharpest recessionary episodes. Second, the turning points detected by both BB algorithm and the rule of thumb are very close to the CEPR ones, whereas the MS model finds that recessions are much shorter. Third, by and large the two mechanical rules can replicate most of the features of the euro area business cycle as recognized by the CEPR dating committee. However, some exceptions stand out. In two cases, for the recessions which are completely disregarded by the MS model the two rules detect the turning point with a two and one quarter lag respectively. The largest difference is for the cycle starting with the 1980Q1 peak: the mechanical rules detect it in 1980Q3, while the CEPR finds that the corresponding trough is in 1982Q3 confirming that the committee looks at many variables than only GDP.

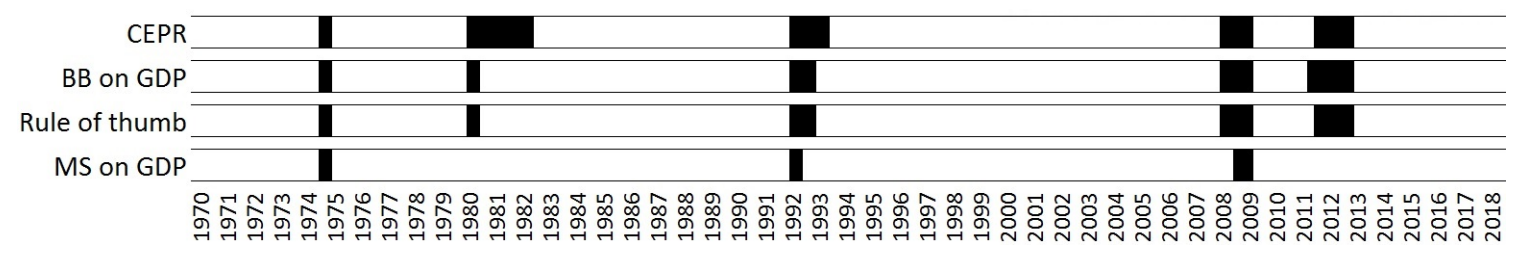

Figure 2: Alternative turning points definition

\section{Methodology}

We estimate a generalized linear model, where $S_{t}$ is the state variable representing the dating, which takes value 0 in expansions and 1 in recessions and $x_{t}$ is a business cycle indicator.

Let $S_{t}$ be the binary response variable, that is distributed as a Bernoulli variable with parameter $\pi_{t}, S_{t} \sim \operatorname{Bin}\left(1, \pi_{t}\right)$ :

$$
\mu_{t}=\mathbb{E}\left[S_{t}\right]=\operatorname{Prob}\left(S_{t}=1\right)=\pi_{t}
$$

and $\mathbf{x}_{t}$ a vector of independent explanatory variables. Define the linear projector $\eta_{t}=\phi^{\prime} \mathbf{x}_{t}$ and the link function $g(\cdot)$, such that $g\left(\mu_{t}\right)=\eta_{t}$. We choose the logit link (i.e. the log-odds):

$$
\eta_{t}=\operatorname{logit}\left(\pi_{t}\right)=\log \left(\frac{\pi_{t}}{1-\pi_{t}}\right)=\log \left(\frac{\operatorname{Prob}\left(S_{t}=1\right)}{\operatorname{Prob}\left(S_{t}=0\right)}\right)
$$


because it is the canonical link such that $\eta_{t}=\theta_{t}$, where $\theta_{t}$ is the canonical parameter obtained from the exponential family representation. ${ }^{8}$ We then get the implicit recession probabilities $\hat{\pi}_{t}=\frac{e^{\hat{\phi}^{\prime} \mathbf{x}_{t}}}{1+e^{\hat{\phi}^{\prime} \mathbf{x}_{t}}}$.

The fitted probabilities obtained through the logit model can be mapped into fitted recession periods on a 0 -or- 1 scale $\left(\hat{\pi}_{t} \mapsto \hat{y}_{t}\right)$ depending on the cutoff $\tau$ in $[0,1]$, such that:

$$
\hat{S}_{t}(\tau)= \begin{cases}1 & \text { if } \hat{\pi}_{t} \geq \tau \\ 0 & \text { if } \hat{\pi}_{t}<\tau\end{cases}
$$

The instinctive choice is the unconditional probability (i.e. the mean or the median probability) or $\tau=0.5$, because it is the value such that $\operatorname{Prob}\left(S_{t}=1\right)>\operatorname{Prob}\left(S_{t}=\right.$ $0)$. In general, for each value of $\tau$ we can construct a 2-by-2 confusion matrix by comparing the observed values $S_{t}$ and the fitted values $\hat{S}_{t}$ (Table 2).

Table 2: Comparison of fitted and actual data

\begin{tabular}{|c|c|c|}
\hline & 0 & 1 \\
\hline 0 & $\begin{array}{c}\text { True Negative } \\
\text { TN }\end{array}$ & $\begin{array}{c}\text { False Positive } \\
\text { FP }\end{array}$ \\
\hline 1 & $\begin{array}{c}\text { False Negative } \\
\text { FN }\end{array}$ & $\begin{array}{c}\text { True Positive } \\
\text { TP }\end{array}$ \\
\hline
\end{tabular}

Two errors can occur: either recession is called but it does not materialize (FP), or the recession hits the economy unexpectedly (FN). Therefore we are interested in two ratios:

- sensitivity, or power of the test, $1-\beta=\operatorname{Prob}\left(\right.$ reject $H_{0} \mid H_{0}$ false $)=\frac{T P}{T P+F N}$ where $\beta$ is the Type II error

- 1 - specificity, or Type I error, $\alpha=\operatorname{Prob}\left(\right.$ reject $H_{0} \mid H_{0}$ true $)=\frac{F P}{F P+T N}$

The Receiver Operating Characteristic (ROC) curve is a curve in $[0,1]^{2}$ that represents the sensitivity $(1-\beta(\tau))$ and 1-specificity $(\alpha(\tau))$ on the two axes, since both are monotone non decreasing functions of $\tau$. The Area under the ROC curve $(A U R O C)$

\footnotetext{
${ }^{8}$ Another possible choice is the probit link $\eta_{t}=\operatorname{probit}\left(\pi_{t}\right)=\Phi^{-1}\left(\pi_{t}\right)$, where $\Phi(\cdot)$ is the cumulative density function of the standard normal distribution. Results using this function are overall consistent with those presented here.
} 
is used to evaluate whether an indicator is able to discriminate between recession and expansion (Peterson and Birdsall, 1953):

$$
A U R O C=\int_{0}^{1} R O C(z) d z
$$

whose sample equivalent can be estimated as:

$$
A U \hat{R} O C=\frac{1}{n_{0} n_{1}} \sum_{i=1}^{n_{0}} \sum_{j=1}^{n_{1}}\left[I\left(X_{i}^{0}>X_{j}^{1}\right)+\frac{1}{2} I\left(X_{i}^{0}=X_{j}^{1}\right)\right]
$$

where $n_{k}$ is the number of times $S_{t}=k$ for $k=0,1, X^{k}$ the distribution of $X$ conditioned on $S_{t}=k$ and $I(\cdot)$ is the indicator function. The estimator is asymptotically normally distributed (Greiner et al., 2000; Hanley and McNeil, 1982; Obuchowski, 1994) with variance equal to:

$$
\begin{gathered}
\sigma^{2}=\frac{1}{n_{0} n_{1}}\left[A U R O C(1-A U R O C)+\left(n_{1}-1\right)\left(Q_{1}-A U R O C^{2}\right)+\left(n_{0}-1\right)\left(Q_{2}-A U R O C^{2}\right)\right] \\
Q_{1}=\frac{A U R O C}{2-A U R O C}, \quad Q_{2}=\frac{2 A U R O C^{2}}{1+A U R O C}
\end{gathered}
$$

It is a measure bounded in $[0.5,1]$ where the higher the AUROC the better the fit. The two extreme cases are:

- perfect classification $(\alpha, \beta \rightarrow 0)$ : the ROC generates the line from $(0,1)$ to $(1,1)$ $(A U R O C=1)$

- perfect randomization between 0 and $1(\alpha=\beta=\tau)$ : the ROC is represented by the angle bisector from $(0,0)$ to $(1,1)(A U R O C=0.5)$.

The optimal cutoff value for $\tau$ is then found as the Youden's statistic (Youden, 1950):

$$
\tau^{*}=\arg \max _{\tau \in[0,1]} 1-\beta(\tau)-\alpha(\tau)
$$

For an univariate model, where $\phi^{\prime} \mathbf{x}_{t}=\phi_{0}+\phi_{1} x_{t}$, the corresponding cut-off value in the $\mathrm{x}$-scale is:

$$
x^{*}=\frac{1}{\phi_{1}}\left(\log \left(\frac{\tau^{*}}{1-\tau^{*}}\right)-\phi_{0}\right)
$$


In practice, looking back at Figure 1, the more separated the probability density functions the higher the AUROC. Berge and Jordà (2011) review the properties of this measure extensively. ${ }^{9}$

Alternative measures of the goodness of fit for models with a dichotomous response variable are available in the literature (see Berge (2015) for a review).

The pseudo $R^{2}$ firstly introduced by McFadden and Zarembka (1974) and later modified by Estrella (1998) is defined as:

$$
\operatorname{pseudo} R^{2}=1-\left(\frac{\log L_{u}}{\log L_{c}}\right)^{-\frac{2}{T} \log L_{c}}
$$

where $L_{c}$ is the likelihood of the (constrained) model of interest and $L_{u}$ is the likelihood of the unconstrained model where all the coefficients are zero but the only constant. It always holds that $\log L_{u} \leq \log L_{c}$. The values 0 and 1 correspond to no fit and perfect fit respectively, and intermediate values have roughly the same interpretations as their analogues in the linear case.

The quadratic probability score (Brier, 1950) is expressed in terms of squared residuals obtained as the difference between the actual values and the fitted probabilities:

$$
Q P S=\frac{1}{T} \sum_{t=1}^{T}\left(S_{t}-\hat{\pi}_{t}\right)^{2}
$$

The better the model the lower the score, where $Q P S=0$ indicates perfect fit. The problem with this metrics is that two models can have different QPS, while leading to the same classification (Hand and Vinciotti, 2003).

\subsection{Data}

GDP data are retrieved in levels from Eurostat. Data before 1995Q1 are backcasted using the AWM database (Fagan et al., 2005). In the following analysis GDP appears transformed in:

- year-on-year growth rate $(G D P-Y)$

- quarter-on-quarter growth rate (annualized, GDP-Q)

\footnotetext{
${ }^{9}$ As Berge and Jordà (2011) notice the ROC can be drawn and the AUROC computed even without estimating a generalized linear model. The ROC is the same for any monotone transformation applied to the data. In order to compute the two ratios the fitted values are obtained on the basis of a threshold $\tau \in \mathbb{R}$, while we consider $\tau \in[0,1]$ to be consistent with the domain of the fitted recession probabilities.
} 
- Hodrick and Prescott (1997) filter (HP filter) with $\lambda=1600$ as suggested for quarterly data $(G D P-H P)$

- band pass filter (Baxter and King, 1999) for frequencies corresponding to cycles lasting between 2 and 8 years $(G D P-B P)$

More data are used in the paper. An extensive description of their source, starting date and transformation applied for making the variable stationary for the factor model are in Table A.1 in Appendix A.

\section{Results}

The persistence of the two states of the economy is represented using the autoclassification function (ACF) introduced by Berge and Jordà (2011) to be the counterpart of the autocorrelation function for binary data. $A C F(h)$ equals the AUROC of a model where the current dating is explained by the past dating:

$$
A C F(h)=A U R O C\left(S_{t+h}, S_{t}\right)
$$

As for the autocorrelation function, the ACF reaches its maximum for $h=0$ $(A C F(0)=1)$ and then decreases. From Figure 3 we notice that the state of the economy at time $t-h$ is informative about the current state of the economy for $h \leq 4$, while for horizons longer than one year the ACF is very close to its lower bound ( 0.5 , analogous to 0 in the correlogram), which is comparable to the performance of a cointoss.

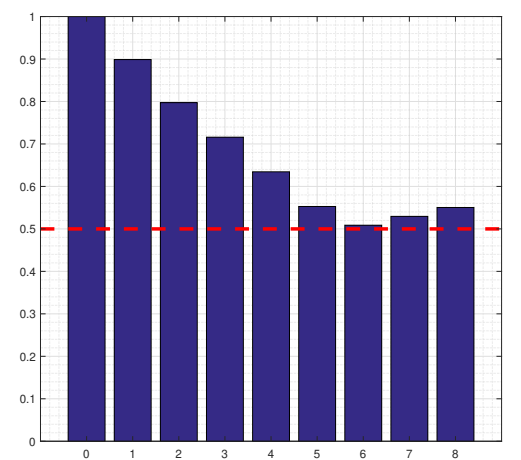

Figure 3: Persistence of CEPR dating 


\subsection{Results based on a single variable}

We start from analyzing how much the CEPR dating is related to GDP. As anticipated in Section 3.1, GDP is transformed in multiple ways to extract the cycle: q-o-q growth rate, y-o-y growth rate, band pass filter, and HP filter. A stream of literature has focused on how detrending methods can influence business cycle evidence and detection of turning points (Canova, 1994; 1998; 1999; Harvey and Jaeger, 1993). In Figure 4 we show the time series together with the shaded areas for the recessions as identified by the CEPR dating committee: we report in the left panel the $\mathrm{y}-\mathrm{O}-\mathrm{y}$ and the annualized q-o-q growth rates which relate to the classical approach of business cycle and in the right panel we display the two other filters (HP and band pass) for completeness, since they describe the growth cycle.

Some findings arise. First, some features of the filters are noticed: the q-o-q growth rate is more volatile than the other series capturing short-run fluctuation and the y-o-y growth rate appears more smoother. Second, while the two growth rates show the same number of turning points, it is however true that the phase shift could interfere in the "correct" turning point detection; the band pass and HP filter detect much shorter cycles (around 5-year duration). In particular, all measures contract during the global financial crisis, but the peak appears in a different quarter and the resulting recession lasts a different number of quarters.

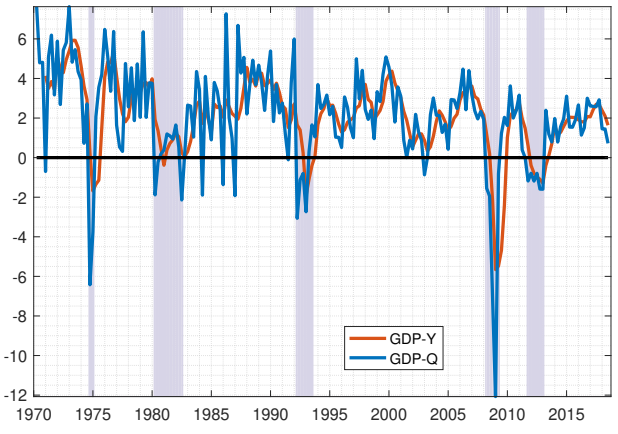

(a) Growth rates

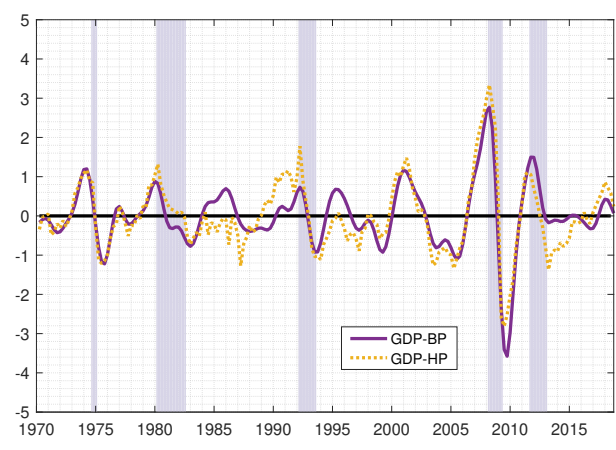

(b) Hodrick-Prescott and band pass filters

Figure 4: GDP and CEPR recessions

Table 3 illustrates the average value of the four transformations of GDP for each episode of recession and expansion. The underlying guess is that recessions are characterized by negative values of growth, while expansions by positive values. In 
particular, the q-o-q growth rates are on average of $-1.5 \%$ during recessions ranging between $-5.1 \%$ for the 1974Q3-1975Q1 recession and $0.2 \%$ for the 1980Q1-1982Q3 one, while it is $2.7 \%$ during expansions with not much variability across the different episodes. The y-O-y growth rates are on average $-0.3 \%$ and $2.4 \%$ during recessions and expansions respectively: the most severe recession appears the 2008Q1-2009Q2 $(-2.4 \%)$ and the mildest one is the 1980Q1-1982Q3 (0.8\%). The cycle extracted with the HP filter is on average $-0.1 \%$ during recessions and 0 during expansions, with some unexpected values. The BP filtered series has an average value of $-0.2 \%$ during recessions and 0 during expansions.

Table 3: Average value of the transformations of GDP during the phases of the cycle

\begin{tabular}{cccccccccc}
\hline \multicolumn{2}{c}{ Turning point } & \multicolumn{2}{c}{ GDP-Q } & \multicolumn{2}{c}{ GDP-Y } & \multicolumn{2}{c}{ GDP-HP } & \multicolumn{2}{c}{ GDP-BP } \\
\hline Peak & Trough & rec. & exp. & rec. & exp. & rec. & exp. & rec. & exp. \\
\hline 1974Q3 & 1975Q1 & -5.1 & 3.5 & -0.7 & 3.0 & -0.7 & 0.0 & -0.5 & 0.0 \\
1980Q1 & 1982Q3 & 0.2 & 2.8 & 0.8 & 2.7 & 0.2 & 0.1 & -0.2 & 0.0 \\
1992Q1 & 1993Q3 & -1.0 & 2.3 & 0.0 & 2.3 & -0.3 & 0.1 & -0.3 & 0.1 \\
2008Q1 & 2009Q2 & -4.7 & 1.8 & -2.4 & 0.8 & 0.0 & -0.4 & -0.6 & -0.6 \\
2011Q3 & 2013Q1 & -1.2 & & -0.7 & & -0.2 & & 0.6 & \\
\hline \multicolumn{2}{c}{ Average } & -1.5 & 2.7 & -0.3 & 2.4 & -0.1 & 0.0 & -0.2 & 0.0 \\
\hline
\end{tabular}

In Table 4 we report the measures of goodness of fit of the different transformations of GDP with respect to the four dating criteria to see whether there are material differences among criteria and whether CEPR dating is based on GDP and, if this is the case, which transformation better expresses the underlying state of the business cycle and at which lag $h^{*}$. The model is:

$$
\mathbb{E}\left[\mathrm{S}_{t+h}\right]=\beta_{0}+\beta_{1} x_{t}
$$

The results confirm that the three measures of goodness of fit are consistent: the ranking among the business cycle indicators at $h=0$ and the lag corresponding to the highest predictive accuracy $h^{*}$ are the same across criteria. Moreover, the different metrics agree on the fact that the q-o-q growth rate captures the change of the state of the business cycle with no lags: on the contrary, the y-o-y growth rate lags 2 quarters and the filtered series need at least 2 quarters. Furthermore, when looking at the four dating criteria, we notice that, although there is a very strong correlation among the rankings of the indicators, the goodness of fit of the CEPR 
dating is slightly different from what we obtain from the BB and the rule of thumb in terms of magnitude. This corroborates the evidence that the CEPR committee not only relies on GDP dynamics.

Despite the two filters reveal weak performances, it is quite hard to notice material differences among the performances of the models on q-o-q and y-o-y growth rates. Regarding the classification procedures, all seem to be equally adequate in discriminating the two phases of the business cycle as described by these GDP transformations.

Table 4: Goodness of fit of dynamic logit with transformations of GDP

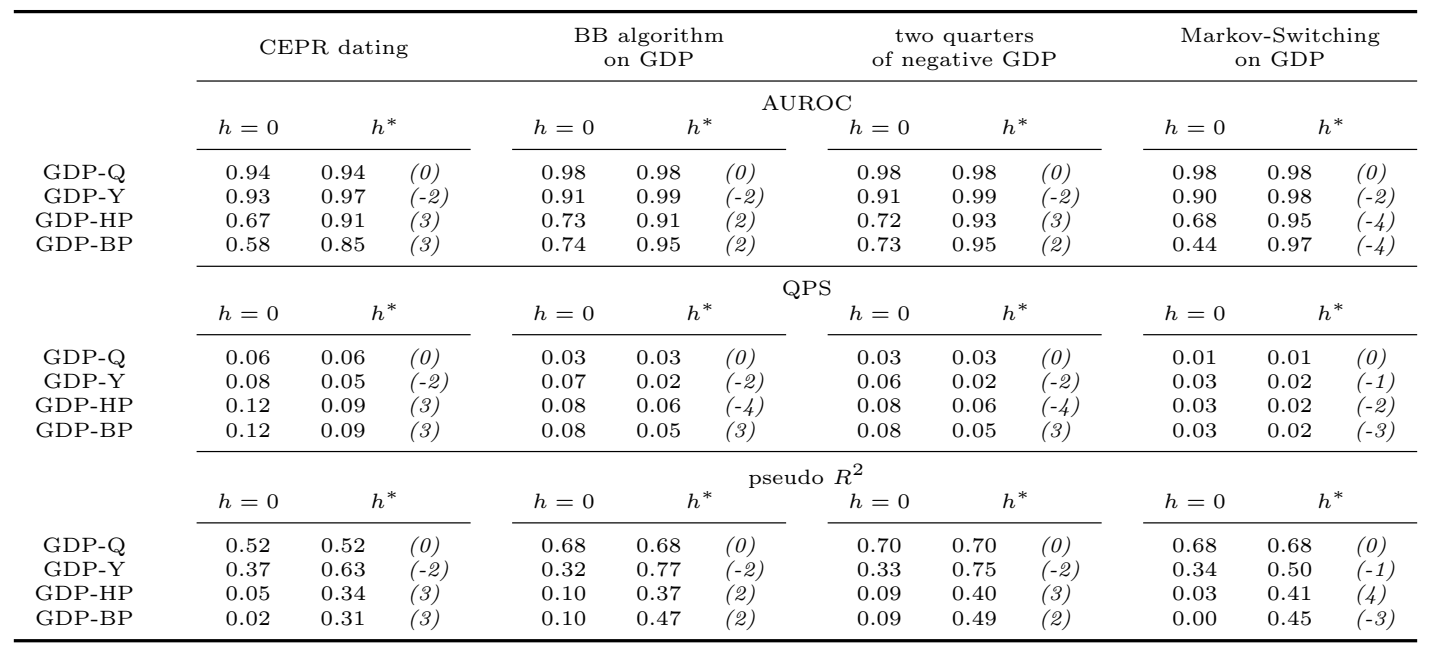

Note: Positive (negative) values of $h^{*}$ indicate that the variable in row leads (lags) the CEPR chronology.

In Figure 5 we illustrate how the ROC curve generated by the model at $h=0$ looks like, focusing of the different GDP transformations. The curves corresponding to the growth rates perform very well for every threshold value $\tau$, leading to AUROCs of almost 0.95. Concerning the filtered series, we notice that the HP filter produces a curve that is dominated by those generated by the q-o-q growth rates and the $\mathrm{y}-\mathrm{O}-\mathrm{y}$ growth rate for every value of $\tau(A U R O C=0.67)$ and the band pass filter is less informative $(A U R O C=0.58)$, even crossing the bisector for some values of $\tau$. Figure 6 shows that for the filtered series the goodness of fit improves as $h$ increases, while for the growth rates the evidence is opposite, because the maximum fit is reached at $h^{*} \leq 0$.

All in all the CEPR seems to do very well. There is however a difference between the peak/trough approach and the above/below trend approach. 


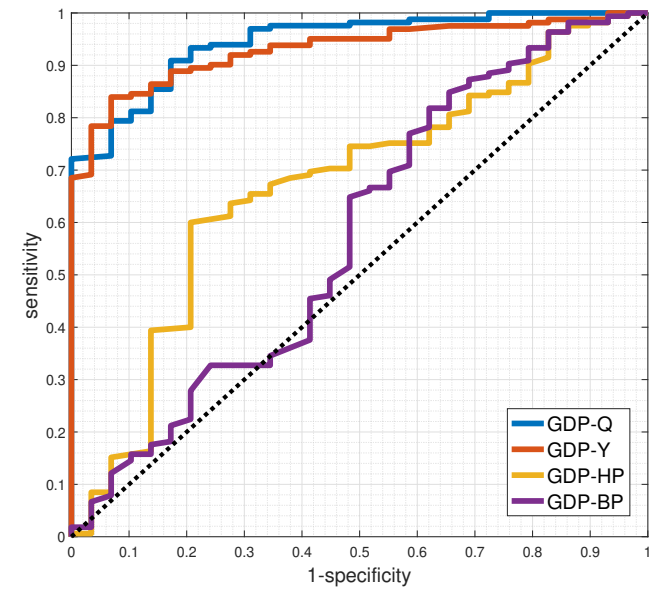

Figure 5: ROC curve for $h=0$

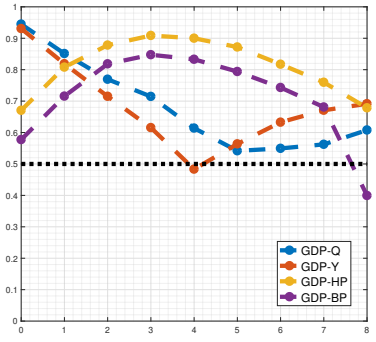

(a) AUROC

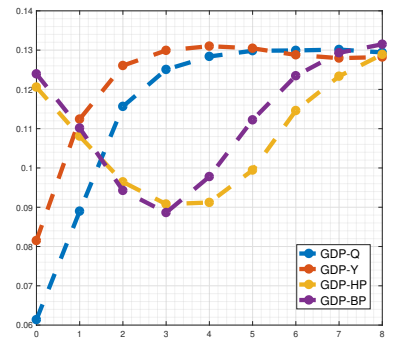

(b) QPS

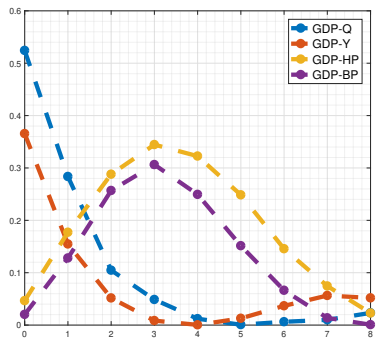

(c) pseudo $R^{2}$

Figure 6: Goodness of fit at different horizons

\subsection{Results based on a multivariate approach}

Since the pioneering work by Burns and Mitchell (1946), the idea that the business cycle could be better described by the comovement of many macroeconomic time series than only one (e.g. GDP or unemployment) has become predominant in the modern macroeconomic literature. Therefore we consider more than 100 indicators of economic activity, such as consumption, labor market data, industrial production. ${ }^{10}$

\footnotetext{
${ }^{10}$ See Appendix A for details.
} 
Some methods can be applied to take into account the richness of information available in a big dataset. Concerning the problem of classification of economic activity we can distinguish the date-then-average approach from the average-then-date approach (Stock and Watson, 2010; 2014).

The date-then-average approach consists in studying the indicators separately and then making an assessment on the business cycle itself. We therefore apply the BB algorithm on each of the variables. ${ }^{11}$ In Figure 7 periods between peaks and troughs (recessions) are in red, while periods between troughs and peaks (expansions) are in green. We notice that the variables strongly comove: for instance, the depression of economic activity during the great financial crisis was widespread to the entire economy. Similar evidence emerge when we analyse soft data. ${ }^{12}$

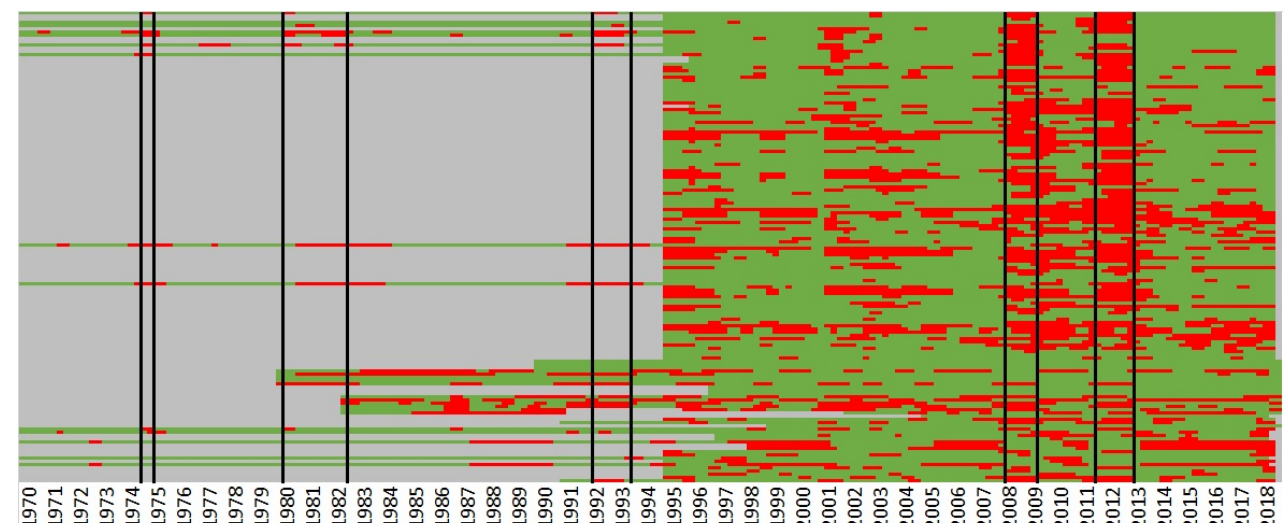

Figure 7: Classification of peaks and troughs as detected through the Bry-Boschan algorithm

In the chart periods between peaks and troughs (recessions) are in red, while periods between troughs and peaks (expansions) are in green. Gray cells identify missing data. Black vertical lines individuate CEPR turning points.

In Figure 8 we report the histogram representing the distribution of turning points together with the corresponding kernel function for peaks or troughs. In general the turning points seem to be fairly synchronized around those individuated by the CEPR committee.

\footnotetext{
${ }^{11}$ As in Burns and Mitchell (1946), time series representing aggregates which increase during recession periods (e.g. unemployment rate) are 'inverted', i.e. transformed in order to decrease during recession.

${ }^{12}$ See Appendix B for details.
} 


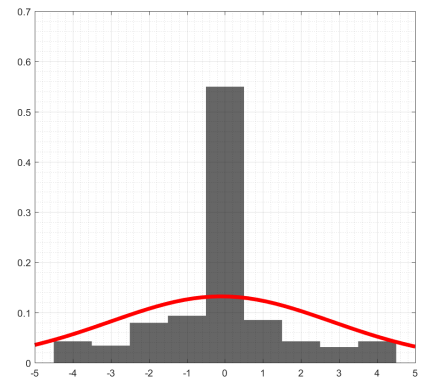

(a) Peaks

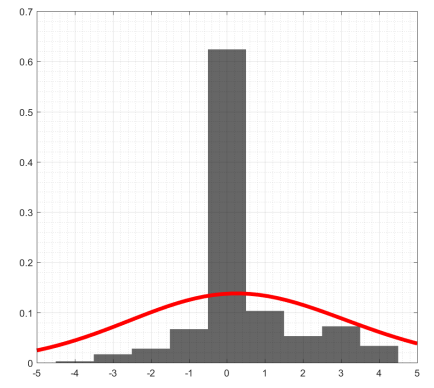

(b) Troughs

Figure 8: Distribution around CEPR turning points

We study each single recession episode, because aggregate evidence could hide heterogeneity across the different episodes (Figure 9). Concerning the recession episodes prior to 1999 we clarify that not many series where available from 1970. Specifically, we reconstructed only 14 time series using the AWM database (Fagan et al., 2005). Starting with the first recession episode we observe that most series individuate the peak one to three quarters earlier than the CEPR (1974Q3) and the following trough one to three quarters later than the CEPR (1975Q1), thus resulting in a longer recession. The 1980Q1 peak is common to most time series and the same happens for the corresponding trough (1982Q3). The 1992Q1 peak has a probability of almost 0.6 and the distribution is quite concentrated around the turning point, while the one relative to the following trough (1993Q3) shows a higher variance. The last two recessions in the sample occurred when the euro area was already established. For what concerns the great recession, both the peak (2008Q1) and the trough (2009Q2) appear in more than half of the indicators although some of the remaining time series identify the turning points in a window of one year around the CEPR ones. The same applies to the sovereign debt crisis, defined as the period from the 2011Q3 peak to the 2013Q3 trough: most indicators individuate the peak contemporaneously or earlier than the CEPR, while only a $10 \%$ show a later peak; most troughs coincide with the one identified by the CEPR signalling a wide spread recovery from the $2013 \mathrm{Q} 4$. 


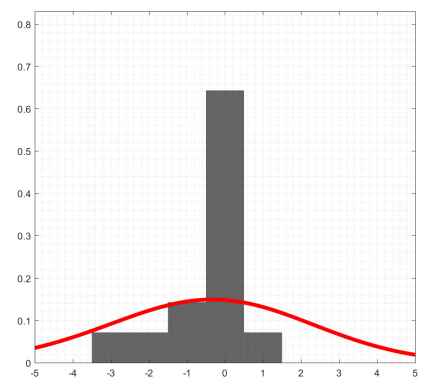

(a) 1974Q3 Peak

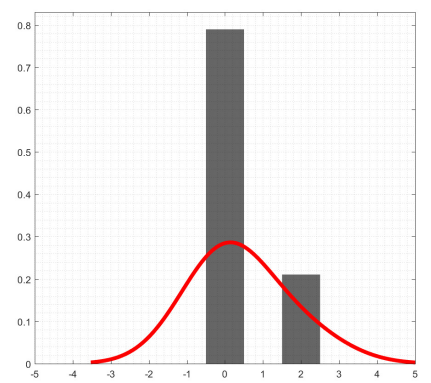

(c) 1980Q1 Peak

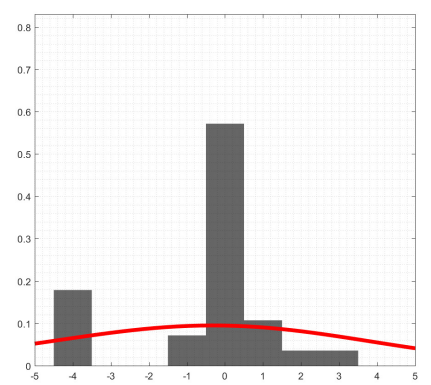

(e) 1992Q1 Peak

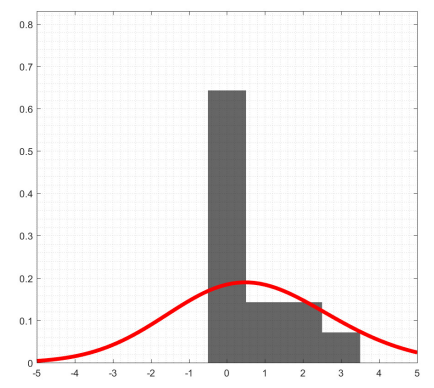

(b) $1975 \mathrm{Q} 1$ Trough

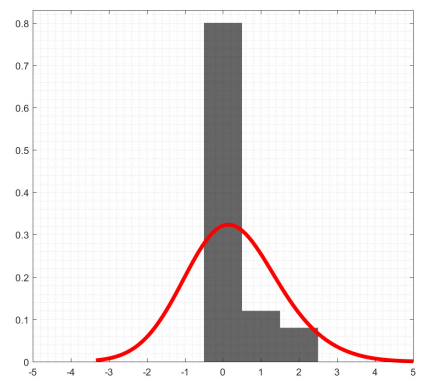

(d) 1982Q3 Trough

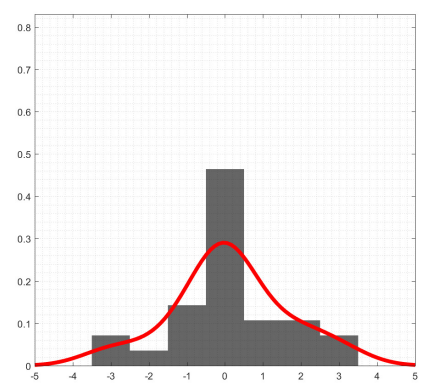

(f) 1993Q3 Trough

Figure 9: Distribution around each CEPR turning point (cont.) 


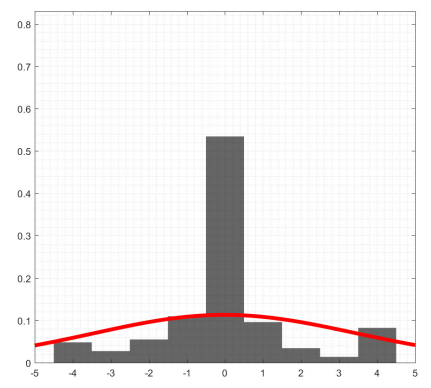

(g) 2008Q1 Peak

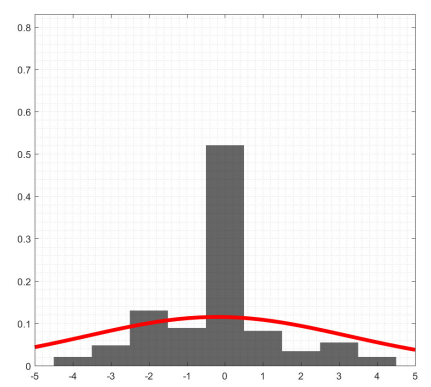

(i) 2011Q3 Peak

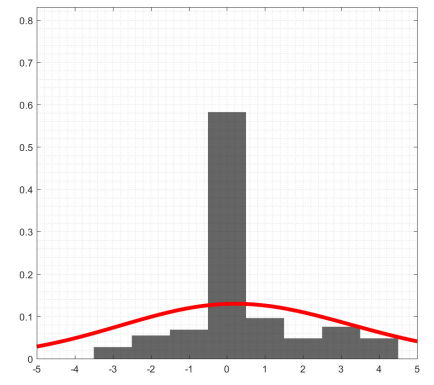

(h) 2009Q2 Trough

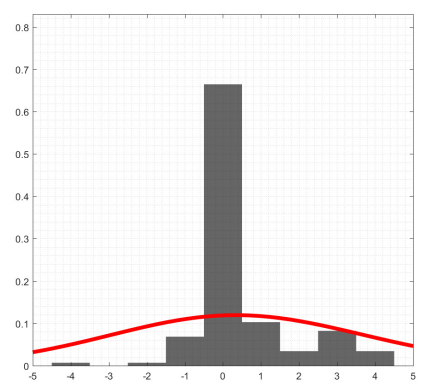

(j) 2013Q3 Trough

Figure 9: (continued) Distribution around each CEPR turning point

We validate the CEPR dating with respect to the macroeconomic variables ${ }^{13}$. The goodness of fit of the models is generally very high and maximum for $h^{*}=0$ (for around almost half of the indicators) pointing at how important these variables are for the assessment of the state of the business cycle formulated by the committee. Some variables reflects however the dynamics of a specific subsector of economic activity which is not really procyclical. Figure 10 shows the distribution of contemporaneous ROCs with different colors identifying levels of goodness of fit: half of the indicators have $A U R O C(0)$ greater than 0.8 (light and dark blue lines) and only $15 \%$ show a fit lower than 0.6 .

\footnotetext{
${ }^{13}$ See Appendix C for details.
} 


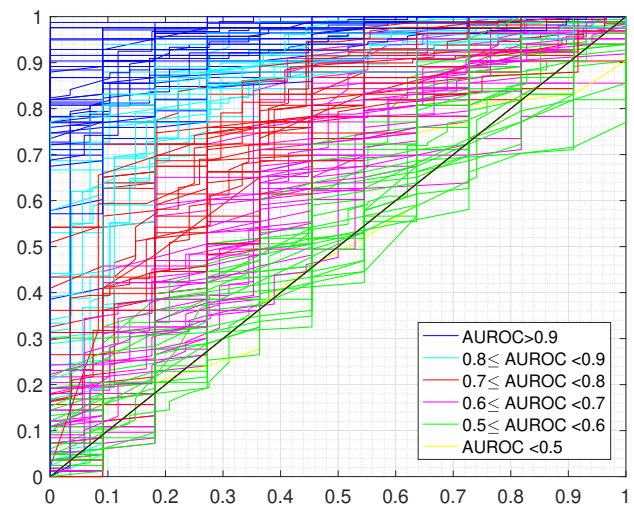

Figure 10: ROC curve at $h=0$ for the different indicators

On the other hand, according to the average-then-date approach there is an effective way to summarize the information of the dataset before classifying economic activity in recessions and expansions. Stock and Watson (2014) suggest to compute a weighted average of the indicators across the cross sectional dimension.

The first method is the static factor model (Stock and Watson, 2002). In a factor model every time series $x_{i t}$ is expressed as the sum of the common component $\chi_{i t}$ and the idiosyncratic component $\epsilon_{i t}$ :

$$
x_{i t}=\chi_{i t}+\epsilon_{i t}=\lambda_{i} \mathbf{F}_{t}+\epsilon_{i t}
$$

where $\mathbf{F}_{t}$ is the $(r \times 1)$ vector of unobservable common factors with $r<<N$ and $\lambda_{i}$ is the $(r \times 1)$ vector of the corresponding factor loadings. The factors are estimated through principal component analysis on the entire dataset.

From the scree analysis we find that two factors are enough to capture the common state underlying the economy as represented by the $N=123$ variables in the dataset. The first two factors explain more than the $30 \%$ of the total variance $(17.3 \%$ and $13.8 \%$ respectively). Specifically, the first factor is highly correlated with GDP $(35.8 \%)$, value added $(47.8 \%)$, industrial production $(54.0 \%)$, while the second one is more correlated with labor market indicator such as employment $(66.2 \%)$, employees $(70.1 \%)$, and unemployment rate $(48.5 \%)$. The two factors explain almost the $50 \%$ of the variance of GDP.

The second method to aggregate consists in weighting the observations with the inverse of the standard deviation normalized by the sum of the standard deviations. 
The resulting time series (ISD) is thus:

$$
x_{t}^{I S D}=\sum_{i=1}^{N} x_{i t} \frac{\operatorname{std}\left(\mathbf{x}_{\mathbf{i}}\right)}{\sum_{i} \operatorname{std}\left(\mathbf{x}_{\mathbf{i}}\right)}
$$

The third aggregation we consider, Eurocoin, is also obtained through a (dynamic) factor model (Altissimo et al., 2001; 2010). Eurocoin is a coincident indicator that summarizes the state of the euro area economy in a single common factor and is released monthly by the CEPR-Bank of Italy. We obtain the quarterly version by simple average of the values of the three months.

The fourth weighted average is the Composite Leading Indicator (CLI) released monthly by the OECD. ${ }^{14}$ The indicator is obtained as a chain-linked Laspeyres index with country-specific weights for the indicators of single countries. In the first place, among many financial and macroeconomic variables the components series are selected according to some criteria: they need to be timely, not materially revised and they should lead the reference series. In the second place the component series are HP-filterd to get the cycles. Finally, the indicator is given as the weighted average of the component series using equal weights.

We then validate the CEPR classification of economic activity with respect to the aggregate indicators. Table 5 reports the goodness of fit of the model for the factors and ISD average: the first factor exhibits the highest contemporaneous AUROC, while the vice versa holds for the pseudo $R^{2}$ with the second factor showing a value higher than the first one; the dynamic model with the ISD series shows a very high goodness of fit. The first factor and the ISD aggregated time series turn out to have the highest in-sample dynamic power at $h^{*}=0$ too. This generally confirms the guess that the committee has in mind a broad definition of economic activity. These conclusions appear even stronger, since Eurocoin is obtained from a dynamic factor model, therefore comparable to the aggregated series. Eurocoin shows the highest goodness of fit according to the three criteria and the maximum concordance with the dating for $h^{*}=-1$, thus pointing to the fact that it is a slightly leading indicator of economic activity. At last, CLI confirms the good capacity to discriminate between recession and expansion.

\footnotetext{
${ }^{14}$ The indicator actually tracks the growth cycle, but it is included for completeness, as in Berge and Jordà (2013) who provide a chronology of turning points for the Spanish business cycle.
} 
Table 5: Goodness of fit of dynamic logit with factors

\begin{tabular}{|c|c|c|c|c|c|c|c|c|c|}
\hline \multirow{2}{*}{ factors } & \multicolumn{3}{|c|}{ AUROC } & \multicolumn{3}{|c|}{ QPS } & \multicolumn{3}{|c|}{ pseudo $R^{2}$} \\
\hline & $h=0$ & & & $h=0$ & & & $h=0$ & & \\
\hline 1 & 0.95 & 0.95 & (0) & 0.08 & 0.08 & (0) & 0.24 & 0.24 & (0) \\
\hline 2 & 0.92 & 0.95 & $(-1)$ & 0.08 & 0.06 & $(-2)$ & 0.34 & 0.52 & $(-2)$ \\
\hline ISD & 0.96 & 0.96 & (0) & 0.05 & 0.05 & (0) & 0.61 & 0.61 & (0) \\
\hline Eurocoin & 0.98 & 1.00 & $(-1)$ & 0.04 & 0.02 & $(-1)$ & 0.71 & 0.84 & $(-1)$ \\
\hline CLI & 0.89 & 0.95 & $(-1)$ & 0.08 & 0.06 & $(-1)$ & 0.37 & 0.51 & $(-1)$ \\
\hline
\end{tabular}

Note: Positive (negative) values of $h^{*}$ indicate that the variable in row leads (lags) the CEPR chronology.

\section{Conclusions}

In this paper we study the classification of the business cycle in recessions and expansions formulated by the CEPR committee for the euro area.

Firstly, we notice that the CEPR dating is not completely in line with alternative dating rules based only on GDP dynamics, thus revealing that the committee considers more indicators. Moreover, when looking individually at each of the variables the classification of economic activity appear to be mainly driven by final consumption and employment. Furthermore, using a big dataset including more than 100 macroeconomic variables we find that the dating proposed by the CEPR committee reflects the business cycle features common to most real macroeconomic time series.

An extension of this framework to country-specific chronologies is left for future research. It would be interesting to define recessions for each single country (see Berge and Jordà (2013) for the Spanish economy) and to study which of the existing macroeconomic variables and indexes better track the business cycles. 


\section{A Data description}

Table A.1: Data description (cont.)

\begin{tabular}{|c|c|c|c|c|}
\hline & Variable & Start date & Source & Trans. \\
\hline 1 & Real GDP & 1970Q1 & Eurostat & 1 \\
\hline 2 & Value added & 1995Q1 & Eurostat & 1 \\
\hline 3 & Final consumption expenditure & 1995Q1 & Eurostat & 1 \\
\hline 4 & Final consumption expenditure of general government & 1970Q1 & Eurostat & 1 \\
\hline 5 & Household and NPISH final consumption expenditure & 1970Q1 & Eurostat & 1 \\
\hline 6 & Gross capital formation & 1995Q1 & Eurostat & 1 \\
\hline 7 & Gross fixed capital formation & 1970Q1 & Eurostat & 1 \\
\hline 8 & Exports of goods and serv. & 1970Q1 & Eurostat & 1 \\
\hline 9 & Exports of goods & 1995Q1 & Eurostat & 1 \\
\hline 10 & Exports of serv. & 1995Q1 & Eurostat & 1 \\
\hline 11 & Imports of goods and serv. & 1970Q1 & Eurostat & 1 \\
\hline 12 & Imports of goods & 1995Q1 & Eurostat & 1 \\
\hline 13 & Imports of serv. & 1995Q1 & Eurostat & 1 \\
\hline 14 & Taxes less subsidies on products & 1970Q1 & Eurostat & 1 \\
\hline 15 & Final consumption expenditure and gross capital formation & 1996Q1 & Eurostat & 1 \\
\hline 16 & Final consumption expenditure, gross capital formation and exports of goods and serv. & 1996Q1 & Eurostat & 1 \\
\hline 17 & Value added & 1995Q1 & Eurostat & 1 \\
\hline 18 & Value added Agriculture, forestry and fishing & 1995Q1 & Eurostat & 1 \\
\hline 19 & Value added Industry (except construction) & 1995Q1 & Eurostat & 1 \\
\hline 20 & Value added Manufacturing & 1995Q1 & Eurostat & 1 \\
\hline 21 & Value added Construction & 1995Q1 & Eurostat & 1 \\
\hline 22 & Value added Wholesale and retail trade, transport, accomodation and food serv. act. & 1995Q1 & Eurostat & 1 \\
\hline 23 & Value added Information and communication & 1995Q1 & Eurostat & 1 \\
\hline 24 & Value added Financial and insurance act. & 1995Q1 & Eurostat & 1 \\
\hline 25 & Value added Real estate act. & 1995Q1 & Eurostat & 1 \\
\hline 26 & Value added Professional, scientific and technical act.; administrative and support serv. act. & 1995Q1 & Eurostat & 1 \\
\hline 27 & Value added Public administration, defence, education, human health and social work act. & 1995Q1 & Eurostat & 1 \\
\hline 28 & Value added Arts, entertainment and recreation; other serv. act. & 1995Q1 & Eurostat & 1 \\
\hline 29 & Total fixed assets & 1995Q1 & Eurostat & 1 \\
\hline 30 & Total Construction & 1995Q1 & Eurostat & 1 \\
\hline 31 & Dwellings & 1995Q1 & Eurostat & 1 \\
\hline 32 & Other buildings and structures & 1995Q1 & Eurostat & 1 \\
\hline 33 & Machinery and equipment and weapons systems & 1995Q1 & Eurostat & 1 \\
\hline 34 & Transport equipment & 1995Q1 & Eurostat & 1 \\
\hline 35 & Cultivated biological resources & 1995Q1 & Eurostat & 1 \\
\hline 36 & Intellectual property products & 1995Q1 & Eurostat & 1 \\
\hline 37 & Total employment Hours Total - all NACE act. & 1995Q1 & Eurostat & 1 \\
\hline 38 & Total employment Hours Agriculture, forestry and fishing & 1995Q1 & Eurostat & 1 \\
\hline 39 & Total employment Hours Industry (except construction) & 1995Q1 & Eurostat & 1 \\
\hline 40 & Total employment Hours Manufacturing & 1995Q1 & Eurostat & 1 \\
\hline 41 & Total employment Hours Construction & 1995Q1 & Eurostat & 1 \\
\hline 42 & Total employment Hours Wholesale and retail trade, transport, accomodation and food serv. act. & 1995Q1 & Eurostat & 1 \\
\hline 43 & Total employment Hours Information and communication & 1995Q1 & Eurostat & 1 \\
\hline 44 & Total employment Hours Financial and insurance act. & 1995Q1 & Eurostat & 1 \\
\hline 45 & Total employment Hours Real estate act. & 1995Q1 & Eurostat & 1 \\
\hline 46 & Total employment Hours Professional, scientific and technical act.; administrative and support serv. act. & 1995Q1 & Eurostat & 1 \\
\hline 47 & Total employment Hours Public administration, defence, education, human health and social work act. & 1995Q1 & Eurostat & 1 \\
\hline 48 & Total employment Hours Arts, entertainment and recreation; other serv. act. & 1995Q1 & Eurostat & 1 \\
\hline 49 & Employees Hours Total - all NACE act. & 1995Q1 & Eurostat & 1 \\
\hline 50 & Employees Hours Agriculture, forestry and fishing & 1995Q1 & Eurostat & 1 \\
\hline 51 & Employees Hours Industry (except construction) & 1995Q1 & Eurostat & 1 \\
\hline 52 & Employees Hours Manufacturing & 1995Q1 & Eurostat & 1 \\
\hline 53 & Employees Hours Construction & 1995Q1 & Eurostat & 1 \\
\hline 54 & Employees Hours Wholesale and retail trade, transport, accomodation and food serv. act. & 1995Q1 & Eurostat & 1 \\
\hline 55 & Employees Hours Information and communication & 1995Q1 & Eurostat & 1 \\
\hline 56 & Employees Hours Financial and insurance act. & 1995Q1 & Eurostat & 1 \\
\hline 57 & Employees Hours Real estate act. & 1995Q1 & Eurostat & 1 \\
\hline 58 & Employees Hours Professional, scientific and technical act.; administrative and support serv. act. & 1995Q1 & Eurostat & 1 \\
\hline 59 & Employees Hours Public administration, defence, education, human health and social work act. & 1995Q1 & Eurostat & 1 \\
\hline 60 & Employees Hours Arts, entertainment and recreation; other serv. act. & 1995Q1 & Eurostat & 1 \\
\hline 61 & Self-employed Hours Total - all NACE act. & 1995Q1 & Eurostat & 1 \\
\hline 62 & Self-employed Hours Agriculture, forestry and fishing & 1995Q1 & Eurostat & 1 \\
\hline
\end{tabular}

Legend for transformation: (1) $\Delta \ln$; (2) $\Delta$; (3) none; (4) seasonally adjusted with TRAMO-SEATS. 
Table A.1: (continued) Data description

\begin{tabular}{|c|c|c|c|c|}
\hline & Variable & Start date & Source & Trans. \\
\hline 63 & Self-employed Hours Industry (except construction) & 1995Q1 & Eurostat & 1 \\
\hline 64 & Self-employed Hours Manufacturing & 1995Q1 & Eurostat & 1 \\
\hline 65 & Self-employed Hours Construction & 1995Q1 & Eurostat & 1 \\
\hline 66 & Self-employed Hours Wholesale and retail trade, transport, accomodation and food serv. act. & 1995Q1 & Eurostat & 1 \\
\hline 67 & Self-employed Hours Information and communication & 1995Q1 & Eurostat & 1 \\
\hline 68 & Self-employed Hours Financial and insurance act. & 1995Q1 & Eurostat & 1 \\
\hline 69 & Self-employed Hours Real estate act. & 1995Q1 & Eurostat & 1 \\
\hline 70 & Self-employed Hours Professional, scientific and technical act.; administrative and support serv. act. & 1995Q1 & Eurostat & 1 \\
\hline 71 & Self-employed Hours Public administration, defence, education, human health and social work act. & 1995Q1 & Eurostat & 1 \\
\hline 72 & Self-employed Hours Arts, entertainment and recreation; other serv. act. & 1995Q1 & Eurostat & 1 \\
\hline 73 & Total employment Persons Total - all NACE act. & 1970Q1 & Eurostat & 1 \\
\hline 74 & Total employment Persons Agriculture, forestry and fishing & 1995Q1 & Eurostat & 1 \\
\hline 75 & Total employment Persons Industry (except construction) & 1995Q1 & Eurostat & 1 \\
\hline 76 & Total employment Persons Manufacturing & 1995Q1 & Eurostat & 1 \\
\hline 77 & Total employment Persons Construction & 1995Q1 & Eurostat & 1 \\
\hline 78 & Total employment Persons Wholesale and retail trade, transport, accomodation and food serv. act. & 1995Q1 & Eurostat & 1 \\
\hline 79 & Total employment Persons Information and communication & 1995Q1 & Eurostat & 1 \\
\hline 80 & Total employment Persons Financial and insurance act. & 1995Q1 & Eurostat & 1 \\
\hline 81 & Total employment Persons Real estate act. & 1995Q1 & Eurostat & 1 \\
\hline 82 & Total employment Persons Professional, scientific and technical act.; administrative and support serv. act. & 1995Q1 & Eurostat & 1 \\
\hline 83 & Total employment Persons Public administration, defence, education, human health and social work act. & 1995Q1 & Eurostat & 1 \\
\hline 84 & Total employment Persons Arts, entertainment and recreation; other serv. act. & 1995Q1 & Eurostat & 1 \\
\hline 85 & Employees Persons Total - all NACE act. & 1970Q1 & Eurostat & 1 \\
\hline 86 & Employees Persons Agriculture, forestry and fishing & 1995Q1 & Eurostat & 1 \\
\hline 87 & Employees Persons Industry (except construction) & 1995Q1 & Eurostat & 1 \\
\hline 88 & Employees Persons Manufacturing & 1995Q1 & Eurostat & 1 \\
\hline 89 & Employees Persons Construction & 1995Q1 & Eurostat & 1 \\
\hline 90 & Employees Persons Wholesale and retail trade, transport, accomodation and food serv. act. & 1995Q1 & Eurostat & 1 \\
\hline 91 & Employees Persons Information and communication & 1995Q1 & Eurostat & 1 \\
\hline 92 & Employees Persons Financial and insurance act. & 1995Q1 & Eurostat & 1 \\
\hline 93 & Employees Persons Real estate act. & 1995Q1 & Eurostat & 1 \\
\hline 94 & Employees Persons Professional, scientific and technical act.; administrative and support serv. act. & 1995Q1 & Eurostat & 1 \\
\hline 95 & Employees Persons Public administration, defence, education, human health and social work act. & 1995Q1 & Eurostat & 1 \\
\hline 96 & Employees Persons Arts, entertainment and recreation; other serv. act. & 1995Q1 & Eurostat & 1 \\
\hline 97 & Self-employed Persons Total - all NACE act. & 1995Q1 & Eurostat & 1 \\
\hline 98 & Self-employed Persons Agriculture, forestry and fishing & 1995Q1 & Eurostat & 1 \\
\hline 99 & Self-employed Persons Industry (except construction) & 1995Q1 & Eurostat & 1 \\
\hline 100 & Self-employed Persons Manufacturing & 1995Q1 & Eurostat & 1 \\
\hline 101 & Self-employed Persons Construction & 1995Q1 & Eurostat & 1 \\
\hline 102 & Self-employed Persons Wholesale and retail trade, transport, accomodation and food serv. act. & 1995Q1 & Eurostat & 1 \\
\hline 103 & Self-employed Persons Information and communication & 1995Q1 & Eurostat & 1 \\
\hline 104 & Self-employed Persons Financial and insurance act. & 1995Q1 & Eurostat & 1 \\
\hline 105 & Self-employed Persons Real estate act. & 1995Q1 & Eurostat & 1 \\
\hline 106 & Self-employed Persons Professional, scientific and technical act.; administrative and support serv. act. & 1995Q1 & Eurostat & 1 \\
\hline 107 & Self-employed Persons Public administration, defence, education, human health and social work act. & 1995Q1 & Eurostat & 1 \\
\hline 108 & Self-employed Persons Arts, entertainment and recreation; other serv. act. & 1995Q1 & Eurostat & 1 \\
\hline 109 & House Prices & 2005Q1 & Eurostat & 1 \\
\hline 110 & Industrial Production (Construction) & 1995Q1 & ECB-SDW & 1,4 \\
\hline 111 & Industrial Production (Total Industry) & 1991Q1 & ECB-SDW & 1,4 \\
\hline 112 & Labor Productivity & 1970Q1 & Eurostat & 1 \\
\hline 113 & Active pop Total & 1970Q1 & Eurostat & 1 \\
\hline 114 & Active pop Males & 1997Q1 & Eurostat & 1 \\
\hline 115 & Active pop Females & 1997Q1 & Eurostat & 1 \\
\hline 116 & Unemployed Total & 1970Q1 & Eurostat & 1 \\
\hline 117 & Unemployed Males & 1998Q2 & Eurostat & 1 \\
\hline 118 & Unemployed Females & 1998Q2 & Eurostat & 1 \\
\hline 119 & Real labour productivity per person & 1995Q1 & Eurostat & 1,4 \\
\hline 120 & Real labour productivity per hour worked & 1995Q1 & Eurostat & 1,4 \\
\hline 121 & Nominal unit labour cost based on persons & 1970Q1 & OECD & 1 \\
\hline 122 & Nominal unit labour cost based on hours worked & 1995Q1 & Eurostat & 1,4 \\
\hline 123 & Unemployment rate & 1970Q1 & Eurostat & 2 \\
\hline 124 & EUROCOIN & 1999Q1 & CEPR-BoI & 3 \\
\hline 125 & CLI & 1970Q1 & OECD & 3 \\
\hline
\end{tabular}

Legend for transformation: (1) $\Delta \ln$; (2) $\Delta$; (3) none; (4) seasonally adjusted with TRAMO-SEATS. 


\section{B Survey data}

Modern business cycle analysis also relies on survey data (Table B.1). Even if they are soft data, which do not correspond to quantitative outcomes, they have many advantages: they are indeed very timely and they can capture the dynamics of the business cycle (Figure B.1).

Survey data are usually available as balance statistics and therefore the interpretation depends on a certain threshold, which can depend on how the balance is computed: quarters are classified as recessions or expansions if they are below or above the threshold respectively. For instance, if the balance is computed as the difference between the positive and negative responses the resulting threshold is ' 0 '.

Table B.1: Survey data description

\begin{tabular}{|c|c|c|c|c|}
\hline & Variable & Start date & Source & Threshold \\
\hline 1 & Industrial confidence indicator & 1985Q1 & EU Commission & 0 \\
\hline 2 & Services confidence indicator & 1985Q1 & EU Commission & 0 \\
\hline 3 & Consumer confidence indicator & 1985Q1 & EU Commission & 0 \\
\hline 4 & Retail trade confidence indicator & 1985Q1 & EU Commission & 0 \\
\hline 5 & Construction confidence indicator & 1985Q1 & EU Commission & 0 \\
\hline 6 & Economic sentiment indicator & 1985Q1 & EU Commission & 100 \\
\hline 7 & Employment expectations indicator & 1985Q1 & EU Commission & 100 \\
\hline 8 & Confidence Indicator $(*)$ & 1985Q1 & EU Commission & 0 \\
\hline 9 & Production trend observed in recent months & 1985Q1 & EU Commission & 0 \\
\hline 10 & Assessment of order-book levels & 1985Q1 & EU Commission & 0 \\
\hline 11 & Assessment of export order-book levels & 1985Q1 & EU Commission & 0 \\
\hline 12 & Assessment of stocks of finished products & 1985Q1 & EU Commission & 0 \\
\hline 13 & Production expectations for the months ahead & 1985Q1 & EU Commission & 0 \\
\hline 14 & Selling price expectations for the months ahead & 1985Q1 & EU Commission & 0 \\
\hline 15 & Employment expectations for the months ahead & 1985Q1 & EU Commission & 0 \\
\hline 16 & Business Climate Indicator & 1985Q1 & EU Commission & 0 \\
\hline 17 & Business Activity Index - services & 1998Q1 & MarkitEcon - PMI & 50 \\
\hline 18 & Backlog orders - manufacturing & 2003Q1 & MarkitEcon - PMI & 50 \\
\hline 19 & Employment index - composite & 1998Q3 & MarkitEcon - PMI & 50 \\
\hline 20 & Employment index - manufacturing & 1997Q3 & MarkitEcon - PMI & 50 \\
\hline 21 & Employment index - services & 1998Q3 & MarkitEcon - PMI & 50 \\
\hline 22 & Stocks of Finished Goods Index - manufacturing & 1997Q3 & MarkitEcon - PMI & 50 \\
\hline 23 & Incoming new business index - composite & 1998Q3 & MarkitEcon - PMI & 50 \\
\hline 24 & Incoming new business index - services & 1998Q3 & MarkitEcon - PMI & 50 \\
\hline 25 & New Orders Index - manufacturing & 1997Q3 & MarkitEcon - PMI & 50 \\
\hline 26 & Outstanding Business Index - services & 1998Q3 & MarkitEcon - PMI & 50 \\
\hline 27 & New export orders index - manufacturing & 1997Q3 & MarkitEcon - PMI & 50 \\
\hline 28 & Output Index - composite & 1998Q3 & MarkitEcon - PMI & 50 \\
\hline 29 & Output Index - manufacturing & 1997Q3 & MarkitEcon - PMI & 50 \\
\hline 30 & Output Prices - manufacturing & 2003Q1 & MarkitEcon - PMI & 50 \\
\hline 31 & Quantity of Purchases Index - manufacturing & 1997Q3 & MarkitEcon - PMI & 50 \\
\hline
\end{tabular}

Note: All variables are obtained as balance statistics. Thresholds are: '0': positive minus negative responses; '50': improvement, no change and deterioration responses are weighted with 1, 0.5, 0 respectively; '100': two composite indicators are rescaled in order to have mean equal to 100.

$\left({ }^{*}\right)$ It is obtained as $(Q 2-Q 4+Q 5) / 3$.

Figure B.1 shows the classification of economic activity as obtained by each of the survey variables. The upper panel refers to the survey produced by the European 
Commission, which are available since 1985, while the lower one regards those produced by Markit Economics from the late 90s. Most of the times periods classified as recession correspond indeed to CEPR recessions, especially in more recent years. The only exception is the period of early 2000s, which the CEPR committee does not define recession, while many survey indicators report a level that is compatible with a deterioration of economic activity.

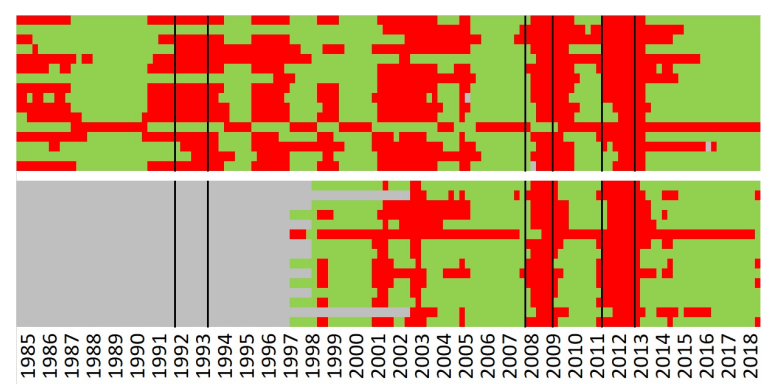

Figure B.1: Classification of peaks and troughs for survey variables

In the chart periods between peaks and troughs (recessions) are in red, while periods between troughs and peaks (expansions) are in green. Gray cells identify missing data. Black vertical lines individuate CEPR turning points. The classification is obtained by using the thresholds in Table B.1. 


\title{
C Results using many macroeconomic variables
}

\author{
Table C.1: Goodness of fit of dynamic logit with many variables (cont.)
}

\begin{tabular}{|c|c|c|c|c|}
\hline \multirow[b]{2}{*}{1} & \multirow{2}{*}{$\frac{\text { Variables }}{\text { Real GDP }}$} & \multirow{2}{*}{$\frac{\operatorname{AUROC}(h=0)}{0.94}$} & \multicolumn{2}{|c|}{$\operatorname{AUROC}\left(h^{*}\right)$} \\
\hline & & & 0.94 & $(0)$ \\
\hline 2 & Value added & 0.98 & 0.98 & (0) \\
\hline 3 & Final consumption expenditure & 0.96 & 0.96 & (0) \\
\hline 4 & Final consumption expenditure of general government & 0.57 & 0.70 & $(-4)$ \\
\hline 5 & Household and NPISH final consumption expenditure & 0.87 & 0.87 & (0) \\
\hline 6 & Gross capital formation & 0.97 & 0.97 & $(0)$ \\
\hline 7 & Gross fixed capital formation & 0.92 & 0.92 & (0) \\
\hline 8 & Exports of goods and serv. & 0.81 & 0.81 & (0) \\
\hline 9 & Exports of goods & 0.87 & 0.87 & (0) \\
\hline 10 & Exports of serv. & 0.78 & 0.80 & $(-1)$ \\
\hline 11 & Imports of goods and serv. & 0.90 & 0.90 & (o) \\
\hline 12 & Imports of goods & 0.96 & 0.96 & $(0)$ \\
\hline 13 & Imports of serv. & 0.75 & 0.78 & (1) \\
\hline 14 & Taxes less subsidies on products & 0.67 & 0.67 & (0) \\
\hline 15 & Final consumption expenditure and gross capital formation & 1.00 & 1.00 & $(0)$ \\
\hline 16 & Final consumption expenditure, gross capital formation and exports of goods and serv. & 0.99 & 0.99 & $(0)$ \\
\hline 17 & Value added & 0.98 & 0.98 & (0) \\
\hline 18 & Value added Agriculture, forestry and fishing & 0.62 & 0.64 & $(-6)$ \\
\hline 19 & Value added Industry (except construction) & 0.94 & 0.94 & (0) \\
\hline 20 & Value added Manufacturing & 0.94 & 0.94 & $(0)$ \\
\hline 21 & Value added Construction & 0.90 & 0.90 & $(0)$ \\
\hline 22 & Value added Wholesale and retail trade, transport, accomodation and food serv. act. & 0.95 & 0.95 & $(0)$ \\
\hline 23 & Value added Information and communication & 0.89 & 0.89 & $(0)$ \\
\hline 24 & Value added Financial and insurance act. & 0.77 & 0.77 & (0) \\
\hline 25 & Value added Real estate act. & 0.66 & 0.73 & $(-6)$ \\
\hline 26 & Value added Professional, scientific and technical act.; administrative and support serv. act. & 0.92 & 0.92 & (0) \\
\hline 27 & Value added Public administration, defence, education, human health and social work act. & 0.70 & 0.71 & $(-6)$ \\
\hline 28 & Value added Arts, entertainment and recreation; other serv. act. & 0.85 & 0.87 & $(-1)$ \\
\hline 29 & Total fixed assets & 0.96 & 0.96 & (0) \\
\hline 30 & Total Construction & 0.95 & 0.95 & $(0)$ \\
\hline 31 & Dwellings & 0.92 & 0.92 & (0) \\
\hline 32 & Other buildings and structures & 0.89 & 0.89 & (0) \\
\hline 33 & Machinery and equipment and weapons systems & 0.96 & 0.96 & (0) \\
\hline 34 & Transport equipment & 0.83 & 0.83 & $(0)$ \\
\hline 35 & Cultivated biological resources & 0.63 & 0.63 & $(0)$ \\
\hline 36 & Intellectual property products & 0.70 & 0.71 & $(-1)$ \\
\hline 37 & Total employment Hours Total - all NACE act. & 0.96 & 0.96 & (0) \\
\hline 38 & Total employment Hours Agriculture, forestry and fishing & 0.60 & 0.70 & $(-7)$ \\
\hline 39 & Total employment Hours Industry (except construction) & 0.90 & 0.90 & (0) \\
\hline 40 & Total employment Hours Manufacturing & 0.91 & 0.91 & (0) \\
\hline 41 & Total employment Hours Construction & 0.97 & 0.97 & (0) \\
\hline 42 & Total employment Hours Wholesale and retail trade, transport, accomodation and food serv. act. & 0.91 & 0.91 & (0) \\
\hline 43 & Total employment Hours Information and communication & 0.64 & 0.79 & $(-5)$ \\
\hline 44 & Total employment Hours Financial and insurance act. & 0.57 & 0.77 & $(-5)$ \\
\hline 45 & Total employment Hours Real estate act. & 0.85 & 0.96 & $(-1)$ \\
\hline 46 & Total employment Hours Professional, scientific and technical act.; administrative and support serv. act. & 0.97 & 0.99 & $(-1)$ \\
\hline 47 & Total employment Hours Public administration, defence, education, human health and social work act. & 0.75 & 0.75 & (0) \\
\hline 48 & Total employment Hours Arts, entertainment and recreation; other serv. act. & 0.59 & 0.71 & $(-1)$ \\
\hline 49 & Employees Hours Total - all NACE act. & 0.95 & 0.95 & (0) \\
\hline 50 & Employees Hours Agriculture, forestry and fishing & 0.64 & 0.69 & $(-7)$ \\
\hline 51 & Employees Hours Industry (except construction) & 0.90 & 0.90 & (0) \\
\hline 52 & Employees Hours Manufacturing & 0.91 & 0.91 & (0) \\
\hline 53 & Employees Hours Construction & 0.97 & 0.97 & (0) \\
\hline 54 & Employees Hours Wholesale and retail trade, transport, accomodation and food serv. act. & 0.88 & 0.90 & $(-1)$ \\
\hline 55 & Employees Hours Information and communication & 0.61 & 0.77 & $(-5)$ \\
\hline 56 & Employees Hours Financial and insurance act. & 0.55 & 0.75 & $(-5)$ \\
\hline 57 & Employees Hours Real estate act. & 0.85 & 0.92 & $(-1)$ \\
\hline 58 & Employees Hours Professional, scientific and technical act.; administrative and support serv. act. & 0.96 & 0.98 & $(-1)$ \\
\hline 59 & Employees Hours Public administration, defence, education, human health and social work act. & 0.74 & 0.74 & (0) \\
\hline 60 & Employees Hours Arts, entertainment and recreation; other serv. act. & 0.60 & 0.72 & $(-4)$ \\
\hline 61 & Self-employed Hours Total - all NACE act. & 0.78 & 0.78 & (o) \\
\hline 62 & Self-employed Hours Agriculture, forestry and fishing & 0.56 & 0.59 & (2) \\
\hline
\end{tabular}




\section{Table C.1: (continued) Goodness of fit of dynamic logit with many variables}

\begin{tabular}{|c|c|c|c|c|}
\hline \multirow[b]{2}{*}{63} & \multirow{2}{*}{$\begin{array}{l}\text { Variables } \\
\text { Self-employed Hours Industry (except construction) }\end{array}$} & \multirow{2}{*}{$\frac{\operatorname{AUROC}(h=0)}{0.65}$} & \multicolumn{2}{|c|}{$\operatorname{AUROC}\left(h^{*}\right)$} \\
\hline & & & 0.67 & $(-1)$ \\
\hline 64 & Self-employed Hours Manufacturing & 0.66 & 0.67 & $(-1)$ \\
\hline 65 & Self-employed Hours Construction & 0.84 & 0.85 & (2) \\
\hline 66 & Self-employed Hours Wholesale and retail trade, transport, accomodation and food serv. act. & 0.70 & 0.70 & (0) \\
\hline 67 & Self-employed Hours Information and communication & 0.75 & 0.78 & $(-1)$ \\
\hline 68 & Self-employed Hours Financial and insurance act. & 0.69 & 0.73 & (2) \\
\hline 69 & Self-employed Hours Real estate act. & 0.71 & 0.81 & $(-1)$ \\
\hline 70 & Self-employed Hours Professional, scientific and technical act.; administrative and support serv. act. & 0.73 & 0.77 & $(-1)$ \\
\hline 71 & Self-employed Hours Public administration, defence, education, human health and social work act. & 0.64 & 0.64 & $(0)$ \\
\hline 72 & Self-employed Hours Arts, entertainment and recreation; other serv. act. & 0.50 & 0.60 & (7) \\
\hline 73 & Total employment Persons Total - all NACE act. & 0.89 & 0.92 & $(-1)$ \\
\hline 74 & Total employment Persons Agriculture, forestry and fishing & 0.61 & 0.70 & $(-6)$ \\
\hline 75 & Total employment Persons Industry (except construction) & 0.77 & 0.83 & $(-1)$ \\
\hline 76 & Total employment Persons Manufacturing & 0.77 & 0.83 & $(-1)$ \\
\hline 77 & Total employment Persons Construction & 0.95 & 0.95 & $(0)$ \\
\hline 78 & Total employment Persons Wholesale and retail trade, transport, accomodation and food serv. act. & 0.88 & 0.89 & $(-2)$ \\
\hline 79 & Total employment Persons Information and communication & 0.63 & 0.82 & $(-5)$ \\
\hline 80 & Total employment Persons Financial and insurance act. & 0.54 & 0.79 & $(-5)$ \\
\hline 81 & Total employment Persons Real estate act. & 0.86 & 0.96 & $(-1)$ \\
\hline 82 & Total employment Persons Professional, scientific and technical act.; administrative and support serv. act. & 0.96 & 0.98 & $(-1)$ \\
\hline 83 & Total employment Persons Public administration, defence, education, human health and social work act. & 0.67 & 0.77 & (4) \\
\hline 84 & Total employment Persons Arts, entertainment and recreation; other serv. act. & 0.54 & 0.71 & $(-5)$ \\
\hline 85 & Employees Persons Total - all NACE act. & 0.91 & 0.93 & $(-1)$ \\
\hline 86 & Employees Persons Agriculture, forestry and fishing & 0.62 & 0.67 & (4) \\
\hline 87 & Employees Persons Industry (except construction) & 0.75 & 0.82 & $(-2)$ \\
\hline 88 & Employees Persons Manufacturing & 0.75 & 0.82 & $(-2)$ \\
\hline 89 & Employees Persons Construction & 0.97 & 0.97 & (0) \\
\hline 90 & Employees Persons Wholesale and retail trade, transport, accomodation and food serv. act. & 0.88 & 0.90 & $(-2)$ \\
\hline 91 & Employees Persons Information and communication & 0.59 & 0.80 & $(-5)$ \\
\hline 92 & Employees Persons Financial and insurance act. & 0.53 & 0.79 & $(-6)$ \\
\hline 93 & Employees Persons Real estate act. & 0.83 & 0.90 & $(-1)$ \\
\hline 94 & Employees Persons Professional, scientific and technical act.; administrative and support serv. act. & 0.95 & 0.97 & $(-1)$ \\
\hline 95 & Employees Persons Public administration, defence, education, human health and social work act. & 0.66 & 0.75 & (4) \\
\hline 96 & Employees Persons Arts, entertainment and recreation; other serv. act. & 0.54 & 0.70 & $(-4)$ \\
\hline 97 & Self-employed Persons Total - all NACE act. & 0.72 & 0.72 & $(0)$ \\
\hline 98 & Self-employed Persons Agriculture, forestry and fishing & 0.54 & 0.61 & (6) \\
\hline 99 & Self-employed Persons Industry (except construction) & 0.57 & 0.65 & $(-1)$ \\
\hline 100 & Self-employed Persons Manufacturing & 0.57 & 0.67 & $(-6)$ \\
\hline 101 & Self-employed Persons Construction & 0.69 & 0.79 & (2) \\
\hline 102 & Self-employed Persons Wholesale and retail trade, transport, accomodation and food serv. act. & 0.67 & 0.68 & $(-1)$ \\
\hline 103 & Self-employed Persons Information and communication & 0.65 & 0.74 & $(-1)$ \\
\hline 104 & Self-employed Persons Financial and insurance act. & 0.67 & 0.68 & (2) \\
\hline 105 & Self-employed Persons Real estate act. & 0.72 & 0.81 & $(-1)$ \\
\hline 106 & Self-employed Persons Professional, scientific and technical act.; administrative and support serv. act. & 0.72 & 0.75 & $(-1)$ \\
\hline 107 & Self-employed Persons Public administration, defence, education, human health and social work act. & 0.55 & 0.59 & $(5)$ \\
\hline 108 & Self-employed Persons Arts, entertainment and recreation; other serv. act. & 0.50 & 0.59 & (7) \\
\hline 109 & House Prices & 0.93 & 0.93 & (0) \\
\hline 110 & Industrial Production (Construction) & 0.88 & 0.88 & (0) \\
\hline 111 & Industrial Production (Total Industry) & 0.96 & 0.96 & (0) \\
\hline 112 & Labor Productivity & 0.77 & 0.77 & $(0)$ \\
\hline 113 & Active pop Total & 0.59 & 0.78 & $(-7)$ \\
\hline 114 & Active pop Males & 0.61 & 0.87 & $(-5)$ \\
\hline 115 & Active pop Females & 0.50 & 0.84 & $(-5)$ \\
\hline 116 & Unemployed Total & 0.92 & 0.92 & (0) \\
\hline 117 & Unemployed Males & 0.98 & 0.98 & (0) \\
\hline 118 & Unemployed Females & 0.95 & 0.95 & (0) \\
\hline 119 & Real labour productivity per person & 0.76 & 0.77 & (1) \\
\hline 120 & Real labour productivity per hour worked & 0.60 & 0.69 & (8) \\
\hline 121 & Nominal unit labour cost based on persons & 0.73 & 0.77 & $(-6)$ \\
\hline 122 & Nominal unit labour cost based on hours worked & 0.57 & 0.58 & (2) \\
\hline 123 & Unemployment rate & 0.96 & 0.96 & (0) \\
\hline
\end{tabular}

Note: Positive (negative) values of $h^{*}$ indicate that the variable in row leads (lags) the CEPR chronology. 


\section{References}

Altissimo, Filippo, Antonio Bassanetti, Riccardo Cristadoro, Mario Forni, Marc Hallin, Marco Lippi, Lucrezia Reichlin, and Giovanni Veronese (2001). "EuroCOIN: a real time coincident indicator of the euro area business cycle". CEPR Discussion Papers.

Altissimo, Filippo, Riccardo Cristadoro, Mario Forni, Marco Lippi, and Giovanni Veronese (2010). "New Eurocoin: tracking economic growth in real time". The Review of Economics and Statistics 92.4, pp. 1024-1034.

Balkan, Binnur (2012). "Dating for individual countries". CEPR mimeo.

Baxter, Marianne and Robert G King (1999). "Measuring business cycles: approximate band-pass filters for economic time series". The Review of Economics and Statistics 81.4, pp. 575-593.

Berge, Travis J (2015). "Predicting recessions with leading indicators: Model averaging and selection over the business cycle". Journal of Forecasting 34.6, pp. 455471.

Berge, Travis J and Òscar Jordà (2011). "Evaluating the classification of economic activity into recessions and expansions". American Economic Journal: Macroeconomics 3.2, pp. 246-77.

- (2013). "A chronology of turning points in economic activity: Spain, 1850-2011". SERIEs 4.1, pp. 1-34.

Brier, Glenn W (1950). "Verification of forecasts expressed in terms of probability". Monthey Weather Review 78.1, pp. 1-3.

Bry, Gerhard and Charlotte Boschan (1971). "Programmed selection of cyclical turning points". Cyclical Analysis of Time Series: Selected Procedures and Computer Programs. NBER, pp. 7-63.

Burns, Arthur F and Wesley C Mitchell (1946). "Measuring business cycles". NBER Books.

Canova, Fabio (1994). "Detrending and turning points". European Economic Review 38.3-4, pp. 614-623.

- (1998). "Detrending and business cycle facts". Journal of monetary economics 41.3 , pp. $475-512$.

- (1999). "Does detrending matter for the determination of the reference cycle and the selection of turning points?" The Economic Journal 109.452, pp. 126-150.

Chauvet, Marcelle and Jeremy Piger (2008). "A comparison of the real-time performance of business cycle dating methods". Journal of Business 86 Economic Statistics 26.1, pp. 42-49. 
Estrella, Arturo (1998). "A new measure of fit for equations with dichotomous dependent variables". Journal of business 85 economic statistics 16.2, pp. 198-205.

Fagan, Gabriel, Jerome Henry, and Ricardo Mestre (2005). "An area-wide model for the euro area". Economic Modelling 22.1, pp. 39-59.

Forni, Mario, Marc Hallin, Marco Lippi, and Lucrezia Reichlin (2000). "The generalized dynamic-factor model: Identification and estimation". Review of Economics and statistics 82.4 , pp. 540-554.

Goldfeld, Stephen M and Richard E Quandt (1973). "A Markov model for switching regressions". Journal of econometrics 1.1, pp. 3-15.

Greiner, Markus, Dirk Pfeiffer, and RD Smith (2000). "Principles and practical application of the receiver-operating characteristic analysis for diagnostic tests". Preventive veterinary medicine 45.1-2, pp. 23-41.

Hamilton, James D (1989). "A new approach to the economic analysis of nonstationary time series and the business cycle". Econometrica: Journal of the Econometric Society, pp. 357-384.

- (1994). Time series analysis. Princeton university press.

- (2011). "Calling recessions in real time". International Journal of Forecasting 27.4, pp. 1006-1026.

Hand, David J and Veronica Vinciotti (2003). "Local versus global models for classification problems: Fitting models where it matters". The American Statistician 57.2 , pp. 124-131.

Hanley, James A and Barbara J McNeil (1982). "The meaning and use of the area under a receiver operating characteristic (ROC) curve." Radiology 143.1, pp. 2936.

Harding, Don and Adrian Pagan (2002). "Dissecting the cycle: a methodological investigation". Journal of monetary economics 49.2, pp. 365-381.

Harvey, Andrew and Albert Jaeger (1993). "Detrending, stylized facts and the business cycle". Journal of applied econometrics 8.3, pp. 231-247.

Hodrick, Robert J and Edward C Prescott (1997). "Postwar US business cycles: an empirical investigation". Journal of Money, Credit, and Banking, pp. 1-16.

McFadden, Daniel and Paul Zarembka (1974). "Frontiers in econometrics". Conditional logit analysis of qualitative choice behavior, pp. 105-142.

Mintz, Ilse (1969). "Dating postwar business cycles: methods and their application to Western Germany, 1950-67". NBER Books.

Obuchowski, Nancy A (1994). "Computing sample size for receiver operating characteristic studies." Investigative Radiology 29.2, pp. 238-243.

Pagan, Adrian (2019). "Business Cycle Issues: Some Reflections on a Literature". Papeles de Economía Española forthcoming. 
Peterson, William Wesley and Theodore Gerald Birdsall (1953). "The theory of signal detectability: Part I, the general theory: Part II, applications with Gaussian noise".

Shiskin, Julius (1974). "The Changing Business Cycle". The New York Times, p. 22.

Stock, James H and Mark W Watson (2002). "Forecasting using principal components from a large number of predictors". Journal of the American statistical association 97.460 , pp. 1167-1179.

- (2010). "Indicators for dating business cycles: Cross-history selection and comparisons". American Economic Review: Papers and Proceedings 100.2, pp. 1619.

- (2014). "Estimating turning points using large data sets". Journal of Econometrics 178 , pp. 368-381.

Youden, William J (1950). "Index for rating diagnostic tests". Cancer 3.1, pp. 32-35. 


\section{RECENTLY PUBLISHED “TEMI” (*)}

N.1306 - Effects of eligibility for central bank purchases on corporate bond spreads, by Taneli Mäkinen, Fan Li, Andrea Mercatanti and Andrea Silvestrini (November 2020).

N. 1307 - On the design of grant assignment rules, by Francesca Modena, Santiago Pereda Fernandez and Giulia Martina Tanzi (December 2020).

N. 1308 - Monetary policy strategies in the New Normal: a model-based analysis for the euro area, by Fabio Busetti, Stefano Neri, Alessandro Notarpietro and Massimiliano Pisani (December 2020).

N.1309 - Rare disasters, the natural interest rate and monetary policy, by Alessandro Cantelmo (December 2020).

N.1310 - The market stabilization role of central bank asset purchases: high-frequency evidence from the COVID-19 crisis, by Marco Bernardini and Annalisa De Nicola (December 2020).

N.1311 - Equity tail risk in the treasury bond market, by Dario Ruzzi and Mirco Rubin (December 2020).

N. 1312 - Scars of youth non-employment and labour market conditions, by Giulia Martina Tanzi (December 2020).

N. 1313 - The COVID-19 shock and a fiscal-monetary policy mix in a monetary union, by Anna Bartocci, Alessandro Notarpietro and Massimiliano Pisani (December 2020).

N.1314 - Working horizon and labour supply: the effect of raising the full retirement age on middle-aged individuals, by Francesca Carta and Marta De Philippis (February 2021).

N.1315 - Bank credit and market-based finance for corporations: the effects of minibond issuances, by Steven Ongena, Sara Pinoli, Paola Rossi and Alessandro Scopelliti (February 2021).

N. 1316 - Is inflation targeting a strategy past its sell-by date?, by Alberto Locarno and Alessandra Locarno (February 2021).

N.1317 - Declining natural interest rate in the US: the pension system matters, by Jacopo Bonchi and Giacomo Caracciolo (February 2021).

N. 1318 - Can we measure inflation expectations using Twitter?, by Cristina Angelico, Juri Marcucci, Marcello Miccoli and Filippo Quarta (February 2021).

N. 1319 - Identifying deposits'outflows in real-time, by Edoardo Rainone (February 2021).

N. 1320 - Whatever it takes to save the planet? Central banks and unconventional green policy, by Alessandro Ferrari and Valerio Nispi Landi (February 2021).

N. 1321 - The power of text-based indicators in forecasting the Italian economic activity, by Valentina Aprigliano, Simone Emiliozzi, Gabriele Guaitoli, Andrea Luciani, Juri Marcucci and Libero Monteforte (March 2021).

N.1322 - Judicial efficiency and bank credit to firms, by Giacomo Rodano (March 2021).

N.1323 - Unconventional monetary policies and expectations on economic variables, by Alessio Anzuini and Luca Rossi (March 2021).

N. 1324 - Modeling and forecasting macroeconomic dowside risk, by Davide Delle Monache, Andrea De Polis and Ivan Petrella (March 2021).

N. 1325 - Foreclosures and house prices, by Michele Loberto (March 2021).

N.1326 - inancial structure and bank relationships of Italian multinational firms, by Raffaello Bronzini, Alessio D’Ignazio and Davide Revelli (March 2021).

(*) Requests for copies should be sent to:

Banca d'Italia - Servizio Studi di struttura economica e finanziaria - Divisione Biblioteca e Archivio storico - Via Nazionale, 91 - 00184 Rome - (fax 003906 47922059). They are available on the Internet www.bancaditalia.it. 
ALBANESE G., M. CIOFFI and P. TOMMASINO, Legislators' behaviour and electoral rules: evidence from an Italian reform, European Journal of Political Economy, v. 59, pp. 423-444, WP 1135 (September 2017).

Aprigliano V., G. ARDIZZI and L. MONTEFORTE, Using the payment system data to forecast the economic activity, International Journal of Central Banking, v. 15, 4, pp. 55-80, WP 1098 (February 2017).

ARnAudo D., G. MiCUCCI, M. RigON and P. Rossi, Should I stay or should I go? Firms' mobility across banks in the aftermath of the financial crisis, Italian Economic Journal / Rivista italiana degli economisti, v. 5, 1, pp. 17-37, WP 1086 (October 2016).

BASso G., F. D'AMURI and G. PERI, Immigrants, labor market dynamics and adjustment to shocks in the euro area, IMF Economic Review, v. 67, 3, pp. 528-572, WP 1195 (November 2018).

BAtini N., G. MELINA and S. VILlA, Fiscal buffers, private debt, and recession: the good, the bad and the ugly, Journal of Macroeconomics, v. 62, WP 1186 (July 2018).

Burlon L., A. NotARPIETRO and M. PISANI, Macroeconomic effects of an open-ended asset purchase programme, Journal of Policy Modeling, v. 41, 6, pp. 1144-1159, WP 1185 (July 2018).

BUSETTI F. and M. CAIVANO, Low frequency drivers of the real interest rate: empirical evidence for advanced economies, International Finance, v. 22, 2, pp. 171-185, WP 1132 (September 2017).

CAPpelletti G., G. GuAZZAROTTI and P. TOMmasino, Tax deferral and mutual fund inflows: evidence from a quasi-natural experiment, Fiscal Studies, v. 40, 2, pp. 211-237, WP 938 (November 2013).

CARDANi R., A. PACCAGNINI and S. VILLA, Forecasting with instabilities: an application to DSGE models with financial frictions, Journal of Macroeconomics, v. 61, WP 1234 (September 2019).

Chiades P., L. Greco, V. Mengotto, L. Moretti and P. Valbonesi, Fiscal consolidation by intergovernmental transfers cuts? The unpleasant effect on expenditure arrears, Economic Modelling, v. 77, pp. 266-275, WP 1076 (July 2016).

CIANI E., F. DAVID and G. DE BLASIO, Local responses to labor demand shocks: a re-assessment of the case of Italy, Regional Science and Urban Economics, v. 75, pp. 1-21, WP 1112 (April 2017).

CIANI E. and P. FISHER, Dif-in-dif estimators of multiplicative treatment effects, Journal of Econometric Methods, v. 8. 1, pp. 1-10, WP 985 (November 2014).

CIAPANNA E. and M. TABOGA, Bayesian analysis of coefficient instability in dynamic regressions, Econometrics, MDPI, Open Access Journal, v. 7, 3, pp.1-32, WP 836 (November 2011).

Coletta M., R. De Bonis and S. Piermattei, Household debt in OECD countries: the role of supply-side and demand-side factors, Social Indicators Research, v. 143, 3, pp. 1185-1217, WP 989 (November 2014).

Cova P., P. PAgano and M. PISANI, Domestic and international effects of the Eurosystem Expanded Asset Purchase Programme, IMF Economic Review, v. 67, 2, pp. 315-348, WP 1036 (October 2015).

ERCOLANI V. and J. VALLE E AZEVEDO, How can the government spending multiplier be small at the zero lower bound?, Macroeconomic Dynamics, v. 23, 8. pp. 3457-2482, WP 1174 (April 2018).

FERRERo G., M. GROSS and S. NERI, On secular stagnation and low interest rates: demography matters, International Finance, v. 22, 3, pp. 262-278, WP 1137 (September 2017).

FoA G., L. GAMBACORTA, L. Guiso and P. E. Mistrulli, The supply side of household finance, Review of Financial Studies, v.32, 10, pp. 3762-3798, WP 1044 (November 2015).

GERALI A. and S. NERI, Natural rates across the Atlantic, Journal of Macroeconomics, v. 62, article 103019, WP 1140 (September 2017).

GIORDANO C., M. MARINUCCI and A. SILVESTRINI, The macro determinants of firms' and households' investment: evidence from Italy, Economic Modelling, v. 78, pp. 118-133, WP 1167 (March 2018).

Gomellini M., D. PELlEGrinO and F. GIFFONI, Human capital and urban growth in Italy, 1981-2001, Review of Urban \& Regional Development Studies, v. 31, 2, pp. 77-101, WP 1127 (July 2017).

LiBERATI D. and M. LOBERTO, Taxation and housing markets with search frictions, Journal of Housing Economics, v. 46, article 101632, WP 1105 (March 2017).

MAGRI S., Are lenders using risk-based pricing in the Italian consumer loan market? The effect of the 2008 crisis, Journal of Credit Risk, v. 15, 1, pp. 27-65, WP 1164 (January 2018).

Mercatanti A., T. MAKINEN and A. SiLVESTRINI, The role of financial factors for european corporate investment, Journal of International Money and Finance, v. 96, pp. 246-258, WP 1148 (October 2017).

MigliettA A., C. Picillo and M. PIETRUnTI, The impact of margin policies on the Italian repo market, The North American Journal of Economics and Finance, v. 50, WP 1028 (October 2015). 
MONTEFORTE L. and V. RAPONI, Short-term forecasts of economic activity: are fortnightly factors useful?, Journal of Forecasting, v. 38, 3, pp. 207-221, WP 1177 (June 2018).

Neri S. and A. NotArpietro, Collateral constraints, the zero lower bound, and the debt-deflation mechanism, Economics Letters, v. 174, pp. 144-148, WP 1040 (November 2015).

PANCRAZI R. and M. Pietrunti, Natural expectations and home equity extraction, Journal of Housing Economics, v. 46, 4, WP 984 (November 2014).

Pereda FERnANDEZ S., Teachers and cheaters. Just an anagram?, Journal of Human Capital, v. 13, 4, pp. 635-669, WP 1047 (January 2016).

RigGi M., Capital destruction, jobless recoveries, and the discipline device role of unemployment, Macroeconomic Dynamics, v. 23, 2, pp. 590-624, WP 871 (July 2012).

2020

Alessandri P. and M. BotTero, Bank lending in uncertain times, R European Economic Review, V. 128, WP 1109 (April 2017).

Antunes A. and V. ERCOLAnI, Public debt expansions and the dynamics of the household borrowing constraint, Review of Economic Dynamics, v. 37, pp. 1-32, WP 1268 (March 2020).

ARduini T., E. PATACChInI and E. RAInONE, Treatment effects with heterogeneous externalities, Journal of Business \& Economic Statistics, , v. 38, 4, pp. 826-838, WP 974 (October 2014).

Bologna P., A. Miglietta and A. Segura, Contagion in the CoCos market? A case study of two stress events, International Journal of Central Banking, v. 16, 6, pp. 137-184, WP 1201 (November 2018).

BotTERo M., F. MEZZANOTTI and S. LENZU, Sovereign debt exposure and the Bank Lending Channel: impact on credit supply and the real economy, Journal of International Economics, v. 126, article 103328, WP 1032 (October 2015).

BRIPI F., D. LOSCHIAVO and D. REVELLI, Services trade and credit frictions: evidence with matched bankfirm data, The World Economy, v. 43, 5, pp. 1216-1252, WP 1110 (April 2017).

BRONZINI R., G. CARAMELLINO and S. MAGRI, Venture capitalists at work: a Diff-in-Diff approach at latestages of the screening process, Journal of Business Venturing, v. 35, 3, WP 1131 (September 2017).

BRONZINI R., S. MOCETTI and M. MONGARDINI, The economic effects of big events: evidence from the Great Jubilee 2000 in Rome, Journal of Regional Science, v. 60, 4, pp. 801-822, WP 1208 (February 2019).

COIBION O., Y. GORODNICHENKO and T. ROPELE, Inflation expectations and firms' decisions: new causal evidence, Quarterly Journal of Economics, v. 135, 1, pp. 165-219, WP 1219 (April 2019).

CORSELlO F. and V. NiSPI LANDI, Labor market and financial shocks: a time-varying analysis, Journal of Money, Credit and Banking, v. 52, 4, pp. 777-801, WP 1179 (June 2018).

COVA P. and F. NATOLI, The risk-taking channel of international financial flows, Journal of International Money and Finance, v. 102, WP 1152 (December 2017).

D'Alessio G., Measurement errors in survey data and the estimation of poverty and inequality indices, Statistica Applicata - Italian Journal of Applied Statistics, v. 32, 3, WP 1116 (June 2017).

DEL PRETE S. and S. FEDERICO, Do links between banks matter for bilateral trade? Evidence from financial crises, Review of World Economic, v. 156, 4, pp. 859 - 885, WP 1217 (April 2019).

D'Ignazio A. and C. MEnOn, The causal effect of credit Guarantees for SMEs: evidence from Italy, The Scandinavian Journal of Economics, v. 122, 1, pp. 191-218, WP 900 (February 2013).

ERCOLANI V. and F. NATOLI, Forecasting US recessions: the role of economic uncertainty, Economics Letters, v. 193, WP 1299 (October 2020).

MAKINEN T., L. SARNO and G. ZINNA, Risky bank guarantees, Journal of Financial Economics, v. 136, 2, pp. 490522, WP 1232 (July 2019).

MOdEnA F., E. RETTORE and G. M. TANZI, The effect of grants on university dropout rates: evidence from the Italian case, Journal of Human Capital, v. 14, 3, pp. 343-370, WP 1193 (September 2018).

NisPi LANDi V., Capital controls spillovers, Journal of International Money and Finance, v. 109, WP 1184 (July 2018).

PERICOLI M., On risk factors of the stock-bond correlation, International Finance, v. 23, 3, pp. 392-416, WP 1198 (November 2018).

RAINONE E., The network nature of OTC interest rates, Journal of Financial Markets, v.47, article 100525, WP 1022 (July 2015). 
RAINONE E. and F. VACIRCA, Estimating the money market microstructure with negative and zero interest rates, Quantitative Finance, v. 20, 2, pp. 207-234, WP 1059 (March 2016).

RIZZICA L., Raising aspirations and higher education. Evidence from the UK's widening participation policy, Journal of Labor Economics, v. 38, 1, pp. 183-214, WP 1188 (September 2018).

SANTIONI, R., F. SCHIANTARELLI and P. STRAHAN, Internal capital markets in times of crisis: the benefit of group affiliation, Review of Finance, v. 24, 4, pp. 773-811, WP 1146 (October 2017).

SCHIANTARELli F., M. STACCHINI and P. STRAHAN, Bank Quality, judicial efficiency and loan repayment delays in Italy, Journal of Finance, v. 75, 4, pp. 2139-2178, WP 1072 (July 2016).

2021

AlBanese G., E. CIANI and G. DE Blasio, Anything new in town? The local effects of urban regeneration policies in Italy, Regional Science and Urban Economics, v. 86, WP 1214 (April 2019).

Fidora M., C. GIORDANO and M. SCHMITZ, Real exchange rate misalignments in the Euro Area, Open Economies Review, v. 32, 1, pp. 71-107, WP 1162 (January 2018).

Li F., A. Mercatanti, T. MAKInEN and A. Silvestrini, A regression discontinuity design for ordinal running variables: evaluating central bank purchases of corporate bonds, The Annals of Applied Statistics, v. 15, 1, pp. 304-322, WP 1213 (March 2019).

LosCHIAvo D., Household debt and income inequality: evidence from Italian survey data, Review of Income and Wealth. v. 67, 1, pp. 61-103, WP 1095 (January 2017).

NisPi LANDi V. and A. SchiAVONE, The effectiveness of capital controls, Open Economies Review, v. 32, 1, pp. 183-211, WP 1200 (November 2018).

Pereda Fernandez S., Copula-based random effects models for clustered data, Journal of Business \& Economic Statistics, v. 39, 2, pp. 575-588, WP 1092 (January 2017).

\section{FORTHCOMING}

Accetturo A., A. Lamorgese, S. Mocetti and D. Pellegrino, Housing Price elasticity and growth: evidence from Italian cities, Journal of Economic Geography, WP 1267 (March 2020).

AlBANeSE G., G. DE BlASIO and A. LOCATELLI, Does EU regional policy promote local TFP growth? Evidence from the Italian Mezzogiorno, Papers in Regional Science, WP 1253 (December 2019).

ANZUINI A. and L. Rossi, Fiscal policy in the US: a new measure of uncertainty and its effects on the American economy, Empirical Economics, WP 1197 (November 2018).

APRIGLIANO V. and D. LIBERATI, Using credit variables to date business cycle and to estimate the probabilities of recession in real time, The Manchester School, WP 1229 (July 2019).

Baltrunaite A., C. Giorgiantonio, S. Mocetti and T. Orlando, Discretion and supplier selection in public procurement, Journal of Law, Economics, and Organization, WP 1178 (June 2018)

COVA P., P. PAgANO, A. NOTARPIETRO and M. PISANI, Secular stagnation, R\&D, public investment and monetary policy: a global-model perspective, Macroeconomic Dynamics, WP 1156 (December 2017).

DE PHILIPPIS M., Multitask agents and incentives: the case of teaching and research for university professors, Economic Journal, WP 1042 (December 2015).

Del Prete S. and M. L. SteFAni, Women as "Gold Dust": gender diversity in top boards and the performance of Italian banks, Economic Notes, Monte dei Paschi di Siena, WP 1014 (June 2015).

HERTWECK M., V. LEWIS and S. VILLA, Going the extra mile: effort by workers and job-seekers, Journal of Money, Credit and Banking, WP 1277 (June 2020).

Metelli L. and F. NATOLI, The international transmission of US tax shocks: a proxy-SVAR approach, IMF Economic Review, WP 1223 (June 2019).

MocetTi S., G. RomA and E. RuBOLINO, Knocking on parents' doors: regulation and intergenerational mobility, Journal of Human Resources, WP 1182 (July 2018).

PERICOLI M. and M. TABOGA, Nearly exact Bayesian estimation of non-linear no-arbitrage term-structure models, Journal of Financial Econometrics, WP 1189 (September 2018). 